Check for updates

Cite this: RSC Adv., 2021, 11, 11844

\title{
Developments in waste tyre thermochemical conversion processes: gasification, pyrolysis and liquefaction
}

\begin{abstract}
N. Nkosi, (D) ${ }^{* a}$ E. Muzenda, ${ }^{b}$ J. Gorimbo (iD) ${ }^{c}$ and M. Belaid ${ }^{a}$
Fossil fuels, particularly crude oil, have proven to be a source of energy to households, transportation and power industries over the past decades. This natural reserve is diminishing at an alarming rate with crude oil having reserves to last the earth for the next half a century. As a result, researchers are constantly seeking remedial technologies to close this gap. Thermochemical conversion processes such as pyrolysis, gasification and liquefaction (PGL) offer an alternative solution to mitigating the world's high reliance on crude oil. These processes can be employed to provide energy, fuel and high-end value-added products. This paper aims to highlight all the research and development advancements and trends that have been made over the past three decades while employing waste tyres and other feedstock. In addition, the prominent countries and their associated researchers who have made novel discoveries in the field of thermochemical conversion are extensively discussed. The research findings show that significant research outputs such as the utilization of vast types of feed materials, the reaction mechanisms, the factors affecting the processes, and the application of the different end-products for thermochemical processes are well documented in the literature. Also, the collected data showed that significant advancements have been achieved in developing PGL technologies. The following conclusions were drawn: (i) PGL technologies show a generally increasing percentage interest from 1990 to 2020, (ii) many authors have identified the end-products obtained from waste feedstocks, such as; waste tyres, biomass, plastics, food waste, microalgae and animal manure to yield promising application benefits, (iii) China has shown the greatest interest in investing into waste to energy initiatives and has demonstrated the vast applications of waste derived products and, (iv) employing waste tyres as a feedstock has shown potential for producing high-end value products in their crude form or refined form. Some of the shortcomings identified during the study are the modest interest shown by most African regions as well as the lack of regulatory frameworks developed by certain countries.
\end{abstract}

Received 21st October 2020

Accepted 20th February 2021

DOI: $10.1039 / \mathrm{d} 0 \mathrm{ra0} 0866 \mathrm{~d}$

rsc.li/rsc-advances of oil per person annually when considering the 2020 global population of 7713 billion. ${ }^{3}$ Energy security is a global concern with the world's natural reserves rapidly diminishing and prices constantly rising. The crude oil supply is also affected by factors such as political instabilities and infrastructure challenges in different regions. As of late, the recently discovered COVID-19 virus, which has become a global pandemic, has significantly affected worldwide economies including the price of crude oil. The benchmarked United States of America (USA) oil price deteriorated to below $\mathbf{\$ 0 . 0 0}$ and the international Brent crude oil fall by nearly $70 \%$ during April of $2020 .{ }^{4}$ The South African petrol price fall by as much as R3.82 in early 2020, from R15.84 in January 2020 to R12.02 in May $2020 .^{5}$ The sharp decline in prices is attributed to fuel oversupply while a low fuel demand was experienced because of the imposed travel restrictions and economic lockdowns. Moreover, the oil price was already being affected by Saudi Arabia and Russia price war, as a result, this phenomenon further impaired the global oil prices. ${ }^{6}$ Other nonconventional sources of oil such as shale oil and sand oil have 
Table 1 A comparison of the prices of crude oil and TDTO from 20112021

\begin{tabular}{lcl}
\hline Year & $\begin{array}{l}\text { Crude oil price } \\
(\text { US \$ bbl per d) }\end{array}$ & $\begin{array}{l}\text { Trye derived } \\
\text { oil price US \$ }\end{array}$ \\
\hline 2011 & 96.91 & \\
2012 & 97.03 & \\
2013 & 100.28 & $0.43 \mathrm{~L}^{-1}$ (ref. 32) \\
2014 & 94.96 & $0.52 \mathrm{~L}^{-1}$ (ref. 33) \\
2015 & 54.14 & \\
2016 & 45.97 & $0.26 \mathrm{~kg}^{-1 a}$ (ref. 34) \\
2017 & 52.74 & \\
2018 & 68.04 & $3.50 \mathrm{~L}^{-1}$ (ref. 28) \\
2019 & 59.60 & $0.844 \mathrm{~L}^{-1}$ (ref. 35) \\
2020 & 42.84 & \\
2021 (January) & 54.41 & \\
${ }^{a}$ Kilograms (kg). & & \\
\end{tabular}

been under exploration globally for the past decades, with China over the past 70 years developing and extracting oil from shale oil to be directly utilized as fuel. ${ }^{7}$ Their limited use has been attributed to the high ash content and lesser aromatic hydrocarbon production from shale oil, ${ }^{8}$ while sand oil showed small concentrations of hydrocarbons (less than 1\%) and a high presence of tailings comprising of an amalgamation of fine clay and sand. ${ }^{9}$

Since the early 90s, researchers have been embarking on research and development of thermochemical conversion processes that will play a critical role in alleviating the energy supply deficiency. The novelty in these processes is that different material feedstocks, commonly coal, ${ }^{10-12}$ including waste products such as waste tyres, ${ }^{12-14}$ biomass; ${ }^{15-17}$ plastics; $;^{18-20}$ food waste $;^{21-23}$ microalgae; ${ }^{24}$ and animal manure ${ }^{25}$ etc. can be employed to yield high-end final products. However, waste tyres will be the core feedstock of discussion in this publication. Waste tyres fall under the general waste category. Their landfilling disposal has been banned in the majority of first world countries such as European Union member states, the USA etc. and third world countries such as South Africa. This has presented a major challenge as waste tyres pose environmental and health risks to the ecosystem. According to Yadav (2020), approximately 3 billion tyres are presently produced all over the world. ${ }^{26-28}$ The USA alone reached tyre production rates of 313 million annually, China, Japan, India and South Africa have significantly produced annual tyres production figures of 239 million (2004), ${ }^{27} 97$ million (2017), ${ }^{29} 80$ million (2010) ${ }^{27}$ and, 16 million $(2015)^{30}$ respectively. Consequently, many of these developed and developing countries have considered the employment of waste tyres in thermochemical processes to yield high-end value products, while simultaneously addressing their waste accumulation challenges. A comparison of the crude oil price bbl per $\mathrm{d}$ over the past decade with the price of tyre derived treated pyrolysis oil (TDTO) obtained from work done by several authors is highlighted in Table 1 . It can be deduced from Table 1 that the highest average oil price which stood at US
$\$ 100.28$ bbl per d was obtained in 2013. This phenomenon was attributed to the substantial decline in Libyans oil production rates accompanied by concerns of instability in other countries, this propelled crude oil prices to rise above US $\$ 100$. When comparing the prices of the two commodities in 2013, the price of crude oil stood at US $\$ 0.63 \mathrm{~L}^{-1}$, however, Ning et al., reported a cost effective selling price of US $\$ 0.43 \mathrm{~L}^{-1}$ which proved to be $32 \%$ more economical than the price of crude oil. Conversely, in 2020 the average price of crude oil was reported to be US $\$ 0.27$ $\mathrm{L}^{-1}$ while Nkosi et al., reported a higher TDTO selling price of US $\$ 0.84 \mathrm{~L}^{-1}$. This excessive price is attributed to the global COVID-19 pandemic, which plummeted oil prices significantly, as highlighted previously. As at January 2021 the average crude oil price stands at US $\$ 0.34 \mathrm{~L}^{-1}$, indicating a steady increase overtime.

Thermochemical processing can be defined as the use of high-temperature conditions to promote the chemical conversion of carbonaceous material under different reaction conditions into energy and a variety of chemical products in different phases.

For instance, thermal degradation methods such: incineration, combustion, and PGL technologies currently exist, with gasification and pyrolysis proving to be more practically applicable and economically sound. ${ }^{36}$ Incineration and combustion have limitations as they require strict toxic gas mitigation steps and the processes do not yield products of economic and practical value. ${ }^{37,38}$ Various process parameters such as reactor configuration, temperature, pressure, heating rate, retention time, reactive or inert environment, expulsion gas flow rate, use of catalyst etc. can be employed to optimize the system and/or the quality of derived products.

Thermochemical conversion research has focused on the production of gaseous, liquid and solid intermediates and subsequently their advancement into fuel and other products. The different processes have the potential of producing a variety of value-added products. ${ }^{39}$ The gaseous fraction produces a gas that is a suitable fuel for electricity production. Depending on the thermochemical process applied, the gas can be further refined to produce transportation fuels through the FischerTrosph process. Hydrogen $\left(\mathrm{H}_{2}\right)$ can be yielded through the water gas shift reaction, methanol and dimethyl ether can also be produced. ${ }^{40}$

Pyrolytic gas produced from waste rubbers has a calorific value range of $29.9-42.1 \mathrm{MJ} \mathrm{m}^{-3}$ (ref. 41) and is abundant in alkanes; alkenes; aromatics; acids, and sulphides, ${ }^{42}$ with aliphatic compounds (chain alkenes and cyclic alkenes), and aromatics (toluene, xylene, styrene) being the most dominant by $70 \%$ and $13.1 \%$ respectively. ${ }^{43}$ The presence of alkenes, cyclohexenes, and aromatics is attributed to the tyres's decomposition of natural rubber. The liquid fraction yielded during the pyrolysis and liquefaction processes have several noteworthy industrial and domestic uses. The oil is an assortment of hydrocarbons comprising of $\mathrm{C}_{6}-\mathrm{C}_{3}$ linear paraffins with $\mathrm{C}_{8}-\mathrm{C}_{13}$ being the most dominant, and with low concentrations of alkene (non-condensed alkenes, pentenes, pentadienes, and isoprene) and aromatics (naphthenes, terpenes, limonene, BTX and, benzopyrenes). ${ }^{41}$ Oliveira Neto et al. observed a directly 
proportional relationship between temperature and the production of aromatic compounds. This can be attributed to the further interactions between the aliphatic and aromatics compounds, as well as and the cyclic formation of aliphatic series. ${ }^{28}$ In crude form, the pyrolytic oil can be used as a combustion fuel $^{\mathbf{4 4}}$ for various industrial machineries such as boilers, kilns and furnaces ${ }^{\mathbf{4 5}}$ and in the road construction industry as asphalt or bitumen. This application has proven to contribute significantly to the diverting of waste tyres away from landfills as no prior treatment of the waste material is required. Pyrolytic oil has been found to reach an energy value of $44 \mathrm{MJ}$ $\mathrm{kg}^{-1} \cdot{ }^{41}$ Yousefi et al. ${ }^{46}$ prepared polymer-improved asphalt using recycled polyethylene and waste tyre-derived oil. Improvements in the performance of the asphalt were achieved at a low range and high temperatures. Upon further refining, pyrolytic oil can be employed as an alternative for transportation fuel or as a diesel blend, ${ }^{29,47}$ it has also demonstrated the potential to be used in the production of limonene (limonene is a suitable chemical in the production of industrial diluents, resins and bonding agent and as a dispersing agent for dyes) and BTX (benzene, toluene and xylene). ${ }^{\mathbf{4 4 , 4 8}}$ Liu et al. pyrolyzed waste tyres inside a multilevel reactor under the temperature span of 85-110 ${ }^{\circ} \mathrm{C}$ and $123-145{ }^{\circ} \mathrm{C}$ respectively to obtain pyrolytic oil. ${ }^{49}$ The authors further refined the oil by employing fractional distillation to achieve significant distillate concentrations of toluene from $7.65 \%$ to $68.52 \%$ and xylene from $10.09 \%$ to $65.20 \% .^{49}$ It has been stated in the literature that the pyrolysis of waste tyres at lower temperatures of approximately $450{ }^{\circ} \mathrm{C}$ yields dipentene; isoprene; other terpenes and aromatics, conversely at higher temperatures above $450{ }^{\circ} \mathrm{C}$ their yields are reduced. ${ }^{50}$ This occurrence is due to the sustained breaking down or aromatic formation of the monomer compounds. Several authors have obtained high yields of dipentene when pyrolyzing waste tyres, Rofiqul et al. ${ }^{51}$ obtained yields of 26.42 weight percent (wt\%) and $27.75 \mathrm{wt} \%$ at temperatures of 425 and $475{ }^{\circ} \mathrm{C}$ respectively using truck tyres. Similarly, Arabiourrutia et al. ${ }^{52}$ obtained a dipentene yield of $23.93 \mathrm{wt} \%$ at $425{ }^{\circ} \mathrm{C}$ when employing passenger vehicle tyres. It can be deduced that high dipentene yields are obtainable at lower pyrolysis operating temperatures. Recently, significant attention has been given to the benefits of the chemicals obtainable from pyrolysis oil, this is due to the less intensive purification steps associated with the chemical feedstock production as well as the firmly established markets that exist for the chemicals. ${ }^{48,53}$ The solid fraction produced during thermochemical conversion is a product of carbon black and other inorganic filling material added in the tyre manufacturing process, and the secondary reactions occurring with the char material during the pyrolysis process. ${ }^{29}$ Literature has shown that the optimal operating temperature for char production is $450{ }^{\circ} \mathrm{C}$ to $550{ }^{\circ} \mathrm{C},{ }^{29}$ a further expansion in temperature results in a reduced char yield. Pyrolytic char contains 85 wt $\%$ of carbon (C), has high porosity and, large surface. These properties place carbon black at a favourable advantage for several potential uses, namely; solid fuel in a form of briquettes; as a carbon source (carbon black) in industrial applications; upon further treatment, the activated carbon from tyres can be used as an adsorbent; catalyst aid ${ }^{54}$ and as a filler in road pavement. ${ }^{55}$ As a carbon black, the solid char is widely applicable in the rubber and tyre manufacturing sector as a filler and colourant in rubber products. Despite the expedient surface morphology of pyrolytic carbon black comprising of comparable properties to industrial carbon black, pyrolytic carbon contains substantial quantities of ash, inorganic impurities and sulphur. ${ }^{29}$ Ucar et al. ${ }^{56}$ Williams and Brindle, ${ }^{57}$ and Gonzalez et al., ${ }^{58}$ reported ash quantities of $18.9 \%, 7.1 \%$ and $3.9 \%$ respectively as well as sulphur concentrations of $1.71 \%$, $1.7 \%$ and $1.5 \%$ respectively on passenger car tyres. As activated carbon, solid char is suitable to be used as an industrial adsorbent due to its minimal volume porosity. At present, sawdust; coconut shell and coal etc. are the predominantly used sources of industrial carbon black. ${ }^{59}$ These natural resources run the risk of depletion in the near future, thus potentially giving rise to a price hike for activated carbon. ${ }^{29}$ Affirmatively, waste tyres provide the opportunity to be used as a source for activated carbon production. However, the major drawback is the necessity for further chemical of physical treatment to meet carbon black industrial grade standards. In the agricultural sector, the use of biochar for soil enhancement has gained traction worldwide and has received attention in recent years. ${ }^{60}$ Carbon char has been recognized for its capabilities for decreasing soil density, raising soil temperature, refining crop yield and nourishing the soil. But, the major drawback is that the application of carbon char in soil can be harmful to the environment and human health, due to the existence of polycyclic aromatic hydrocarbons and volatile organic compounds, thus limiting its use to some extent. The process economics of pyrolysis have shown that the successes of waste pyrolysis is highly dependant on the quality and applicability of the final product streams. In that regard, Arabiourrutia ${ }^{61}$ and Miandad ${ }^{62}$ have demonstrated the benefits of waste tyre catalytic pyrolysis while employing natural and synthetic zeolite catalyst as well as acidic and basic catalysts. The advantageous use of catalytic material has been shown to (i) improve the waste tyre pyrolysis gas and liquid yields, (ii) selectively produce valuable chemicals, such as light alkenes or aromatics compounds, (iii) minimize the sulphur content in tyre derived oil and, (iv) increase $\mathrm{H}_{2}$ content in the gas product. ${ }^{61}$

\section{Waste tyres as a thermochemical process feedstock}

Commercial vehicle tyres are manufactured from rubber (45$55 \mathrm{wt} \%$ ), carbon black (20-35 wt\%), metal textile (15-25 wt\%), zinc oxide (1-3 wt\%), sulphur (1-2 wt\%) and additives (5$7 \mathrm{wt} \%) .{ }^{63}$ Vehicle tyres consists of a combination of natural (NR) and synthetic rubber (SR), namely; butyl rubber (BR) and styrene butadiene rubber (SBR). NR is employed due to its suitable tear resistant strength, superior bonding strength and rolling resistance. SBR promotes better tyre abrasion resistance and grip properties when compared with NR, also, SBR is widely applied in tyre treads casing and sidewalls. ${ }^{64}$ The tyre production pathway includes the vulcanisation process's employment, where a non-reversible reaction among the different chemicals 
Table 2 The proximate and ultimate properties of waste tyres and waste tyre derived oil

\begin{tabular}{|c|c|c|c|c|c|c|c|c|c|}
\hline \multirow{2}{*}{$\begin{array}{l}\text { Parameters } \\
\text { Ref. }\end{array}$} & \multicolumn{3}{|c|}{$\begin{array}{l}\text { Proximate and ultimate values of } \\
\text { unprocessed waste tyres }\end{array}$} & \multirow{2}{*}{$\begin{array}{l}\text { Proximate and ultimate } \\
\text { analysis of commercial } \\
\text { diesel oil }\end{array}$} & \multirow{2}{*}{$\begin{array}{l}\text { Parameters } \\
\text { Ref. }\end{array}$} & \multicolumn{4}{|c|}{$\begin{array}{l}\text { Proximate and } \\
\text { ultimate values of } \\
\text { waste tyre derived oil }\end{array}$} \\
\hline & 80 & 64 & 81 & & & 82 & 83 & 84 & 85 \\
\hline Carbon (wt\%) & $83.45-85.60$ & $83-88$ & 86.64 & 87.4 & Carbon (wt\%) & 84.2 & 86.3 & 82.6 & 75.50 \\
\hline Hydrogen (wt\%) & $9.59-11.73$ & $9.6-11.4$ & 10.56 & 12.1 & Hydrogen (wt\%) & 7.9 & 7.1 & 8.2 & 0.70 \\
\hline Oxygen (wt\%) & $0.10-3.96$ & $0.1-4.0$ & 0.78 & 0.29 & Oxygen (wt\%) & 5.5 & 4.5 & 6.1 & 13.10 \\
\hline Nitrogen (wt\%) & $0.4-1.05$ & $0.4-1.0$ & 1.32 & 370 (ppm) & Nitrogen (wt\%) & 1.0 & 0.5 & 0.9 & 0.00 \\
\hline Total sulphur (wt\%) & $0.72-0.96$ & $0.6-1.6$ & 0.69 & 0.29 & Total sulphur (wt\%) & 1.4 & 1.7 & 2.2 & 5.60 \\
\hline Calorific value $\left(\mathrm{MJ} \mathrm{kg}^{-1}\right)$ & $38-42.8$ & $\begin{array}{l}\text { HHV: } 41-46 \\
\text { LHV: } 31-37\end{array}$ & HHV: 42.76 & 45.5 & Calorific Value $\left(\mathrm{MJ} \mathrm{kg}^{-1}\right)$ & - & - & - & 38.6 \\
\hline Viscosity@40ㄷ (cSt) & 3.2 & $2-21\left(\mathrm{~mm}^{2} \mathrm{~s}^{-1}\right)$ & 2.60 & 2.1 & Moisture (wt\%) & 1.8 & 0.4 & 1.1 & 0.80 \\
\hline Flash point $\left({ }^{\circ} \mathrm{C}\right)$ & 43 & $13-60$ & - & 54 & Volatiles (wt\%) & 64.5 & 59.9 & 66.8 & 64.50 \\
\hline Aromatic content $(\mathrm{m} / \mathrm{m} \%)$ & $39.3-63$ & - & - & & Fixed carbon (wt\%) & 26.3 & 21 & 28.5 & 29.60 \\
\hline Density@15 ${ }^{\circ} \mathrm{C}\left(\mathrm{kg} \mathrm{m}^{-3}\right)$ & 920 & $900-1000$ & 888.29 & 838 & Ash (wt\%) & 7.4 & 18.4 & 3.6 & 5.10 \\
\hline
\end{tabular}

and feed materials results in crosslinks of rubber polymeric sequences of strong bridges between molecules. The crosslinked elastomers are rigid, insoluble and inseparable thermoset. ${ }^{47}$ Waste tyres possess a relatively high heating value (38$\left.45.0 \mathrm{MJ} \mathrm{kg}^{-1}\right)^{14}$ relative to other waste materials such as biomass (22.2-28.5 MJ kg $\left.{ }^{-1}\right){ }^{65}$ food waste (3.667-9.920 MJ kg $\left.{ }^{-1}\right){ }^{66}$ animal manure (12-15 $\left.\mathrm{MJ} \mathrm{kg}^{-1}\right)^{25}$ and plastics $\left(24-44 \mathrm{MJ} \mathrm{kg}^{-1}\right)^{67}$ as well as common fossil fuels such coal lignite (16.98 $\left.\mathrm{MJ} \mathrm{kg}^{-1}\right)$ and subbituminous $\left(33.04 \mathrm{MJ} \mathrm{kg}^{-1}\right){ }^{68}$

Waste tyres are a popular thermochemical process feedstock due to their high carbon content, as deduced from Table 2. The carbon content of waste tyres, tyre derived oil (TDO) and conventional diesel oils is comparable. As a result, this makes the solid char produced favourable for use in the carbon black industry. Commercial carbon blacks have been reported to have an elemental carbon content of approximately $97.00 \mathrm{wt} \% .^{69}$ Zhang et al., after employing the pickling process on pyrolytic char, reported a carbon content increase from $81.79 \%$ to $97.18 \%$, thus, making pyrolysis derived char comparable with commercial carbon blacks. ${ }^{70}$ TDO is one of the main products of interest when employing thermochemical processes. A comparison study of the properties of waste tyres, TDO and conventional diesel oils is carried out in Table 2 . The flashpoint of TDO is essentially lower than that of commercial diesel fuel, this brings about fire concerns pertaining to the suitability of oil storage and transportation. Zhang et al., has attributed the low flash point to the high presence of volatile hydrocarbons in the TDO. ${ }^{14}$ The high density of TDO has damaging effects in the combustion engine's performance and also generates sulphur dioxide $\left(\mathrm{SO}_{2}\right)$, noxious oxide $\left(\mathrm{NO}_{x}\right)$, carbon monoxide (CO), hydrocarbons and smoke emissions in the exhaust gas. ${ }^{71}$ Lastly, a low viscosity is preferred for the purpose of aiding oil pumping and engine performance. Comparing the properties of TDO with those of conventional diesel oil, it can be said that the two oils can be paralleled together. However, the upgrading of TDO with chemical and physical techniques may be explored to further enhance the properties of TDO. Physical properties such as distillation; have been found to enhance TDO general properties of crude TPO, namely: density, viscosity, heating value and flash point. ${ }^{72}$ Desulfurization, hydrotreating has been found to reduce sulphur and water content, ${ }^{73}$ hydrodenitrification removes nitrogen compounds, ${ }^{\mathbf{1 4}}$ also, other chemical treatment processes may be employed.

TDO has been shown to have the potential to be used in different industries, a few of the industries are discussed in the section to follow. Several authors have performed the practise of TDO blending with diesel with the aim of enhancing the fuel properties of TDO and to better the emission performance. ${ }^{\mathbf{1 4}}$ Umeki et $a .^{74}$ observed that the mixture of TDO and diesel reduced the density and dynamic viscosity, whereas the heating value displayed a directly proportional increase with increasing diesel content. Lastly, Karagoz et al. ${ }^{75}$ noted that the cetane number of the blended oil mixture was reduced to quantities lower than conventional diesel standard, as a result, this considerably affects the combustion properties and gas emissions. As a result, more work still needs to be done due to the substandard performance of the TDO and diesel blend pertaining engine and combustion performance as well as the produced higher emission levels. Limonene is reported to be a high-value primary material in the chemicals industry with several noteworthy applications. It can be utilized as a natural cleaning solvent, in the production of fragrance, adhesives, pigment dispersant agents and as a food-additive. ${ }^{50}$ The presence of benzene, toluene and xylene (BTX) in TDO had given the waste product renewed attention due to their wide industrial use. Benzene is used to synthesize pigments, rubber, fibres, plastics etc.; toluene is used in the industry to produce medicines, pesticides, dyes and xylene is mainly utilized in the production of plastics. ${ }^{\mathbf{1 4}}$

\section{Gasification technology}

Gasification is a sub-stoichiometric thermochemical process that transforms carbon-based feedstock through gasifying agent's controlled supply into a fuel gas. ${ }^{76,77}$ The chemo-physical observations that transpire during the gasification of tyres are 


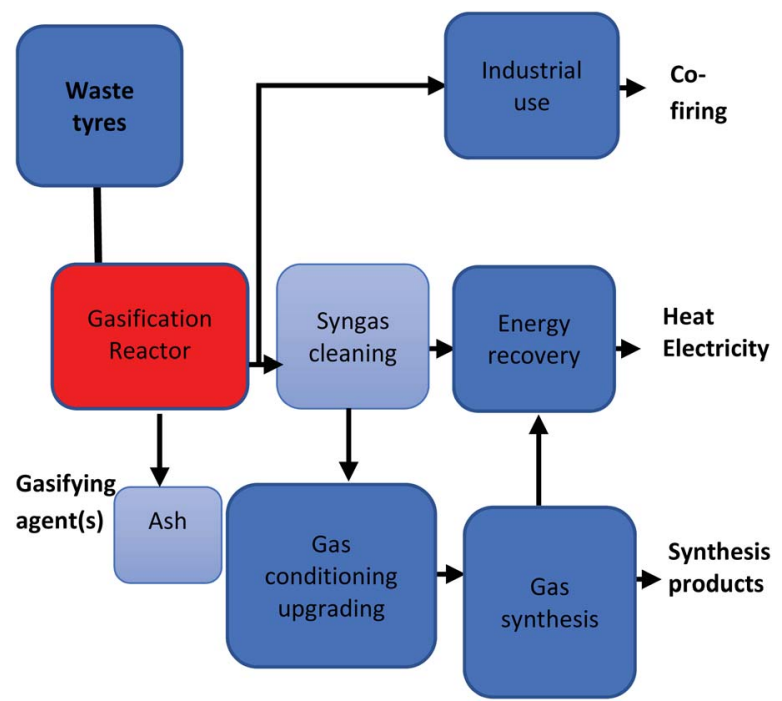

Fig. 1 Waste tyre gasification process pathway. ${ }^{36}$

generally similar to conventional carbonaceous material subjected to thermal depolymerization. This comprises of drying, devolatilization, heat conduction, fissuring, shrinkage, and fragmentation of solid particles. ${ }^{78}$ The gasification process is more multifaceted than the pyrolysis process, it consists of heterogeneous and homogeneous reaction mechanisms. During the heterogeneous reaction, the chemical reactions occurs over the surface of the material, as a result, the rates of conversion is highly depend on factors such as surface area, surface ease of access, carbon active sites, concentration of inorganic matter, and the composition of the gasification agent. ${ }^{54}$ In contrast to the heterogeneous reactions, the homogeneous reaction are nearly instantaneous under elevated thermal conditions. ${ }^{79}$ The initial depolymerization reaction entails the decomposition of tyres resulting in heavy and light hydrocarbons as well as solid char.

The secondary reactions include the disintegrating of the heavy hydrocarbons, the reforming of light and heavy hydrocarbons and the further volarization of the solid char fraction to expand gas production. ${ }^{86}$ The resultant synthesis gas (syngas), encompasses a complex mixture of $\mathrm{H}_{2}$, $\mathrm{CO}$, carbon dioxide $\left(\mathrm{CO}_{2}\right)$, methane $\left(\mathrm{CH}_{4}\right)$ and other light hydrocarbons. Fig. 1 illustrates a basic waste tyre gasification process pathway and reactions R1 to R10 shows the reactions involved in the gasification process.$^{87}$ Lee et al.$^{88}$ proposed that the application of R1 to R10 reaction during the steam reforming of municipal solid waste rubber can also be applicable for the gasification of waste tyre. Reactive agents such as air, oxygen $\left(\mathrm{O}_{2}\right)$, steam/water, $\mathrm{H}_{2}$ (ref. 36) and $\mathrm{CO}_{2}$ (ref. 89) can be utilized as gasifying agents.

Heterogeneous reactions

Char partial combustion

$$
\mathrm{C}(\mathrm{s})+0.5 \mathrm{O}_{2}(\mathrm{~g})=\mathrm{CO}(\mathrm{g})(-111 \mathrm{MJ})(\mathrm{kmol})^{-1}
$$

Boudouard reaction

$$
\mathrm{C}(\mathrm{s})+\mathrm{CO}_{2}(\mathrm{~g}) \leftrightarrow 2 \mathrm{CO}(\mathrm{g})(+172 \mathrm{MJ})(\mathrm{kmol})^{-1}
$$

Water-gas reaction

$$
\mathrm{C}(\mathrm{s})+\mathrm{H}_{2} \mathrm{O}(\mathrm{g}) \leftrightarrow \mathrm{CO}(\mathrm{g})+\mathrm{H}_{2}(\mathrm{~g})(+131 \mathrm{MJ})(\mathrm{kmol})^{-1}
$$

Methanation

$$
\mathrm{C}(\mathrm{s})+2 \mathrm{H}_{2}(\mathrm{~g}) \leftrightarrow \mathrm{CH}_{4}(\mathrm{~g})(75 \mathrm{MJ} /(\mathrm{kmol})
$$

Homogeneous reactions

CO partial combustion

$$
\mathrm{C}(\mathrm{s})+0.5 \mathrm{O}_{2}(\mathrm{~g})=\mathrm{CO}(\mathrm{g})(-283 \mathrm{MJ})(\mathrm{kmol})^{-1}
$$

$\mathrm{H}_{2}$ partial combustion

$$
\mathrm{H}_{2}(\mathrm{~g})+0.5 \mathrm{O}_{2}(\mathrm{~g})=\mathrm{H}_{2} \mathrm{O}(\mathrm{g})(-242 \mathrm{MJ})(\mathrm{kmol})^{-1}
$$

CO shift

$\mathrm{CO}(\mathrm{g})+\mathrm{H}_{2} \mathrm{O}(\mathrm{g}) \leftrightarrow \mathrm{CO}_{2}(\mathrm{~g})+\mathrm{H}_{2}(\mathrm{~g})(-14 \mathrm{MJ})(\mathrm{kmol})^{-1}$

Steam methane reformimg

$\mathrm{CH}_{4}(\mathrm{~g})+\mathrm{H}_{2} \mathrm{O}(\mathrm{g})=\mathrm{CO}(\mathrm{g})+3 \mathrm{H}_{2}(\mathrm{~g})(+206 \mathrm{MJ})(\mathrm{kmol})^{-1}$

Hydrogen sulphide and ammonia formation reactions $\mathrm{H}_{2} \mathrm{~S}$ formation

$$
\mathrm{H}_{2}(\mathrm{~g})+\mathrm{S}(\mathrm{s})=\mathrm{H}_{2} \mathrm{~S}(\mathrm{~g})
$$

$\mathrm{NH}_{3}$ formation

$$
0.5 \mathrm{~N}_{2}(\mathrm{~g})+1.5 \mathrm{H}_{2}(\mathrm{~g})=\mathrm{NH}_{3}(\mathrm{~g})
$$

Sulphur (S), nitrogen (N), hydrogen sulphide $\left(\mathrm{H}_{2} \mathrm{~S}\right)$, ammonia $\left(\mathrm{NH}^{3}\right)$, gas $(\mathrm{g})$, solid (s)

The heating value and the resultant gas constituents are highly reliant on the gasifying agent amongst other factors. ${ }^{40}$ Air gasification has been advanced to industrial scale due to its abundant availability. ${ }^{90}$ However, some of the advantages of employing air as a gasifying agent are the high nitrogen concentration in the product gas and the reduced lower heating value (LHV), 4-6 $\mathrm{MJ} \mathrm{N} \mathrm{m}^{-3}$. ${ }^{91}$ The inverse can be said regarding the use of oxygen as a gasifying agent, oxygen must be purchased or generated at a cost for use in the process. However, it yields a final product gas of higher LHV (10-15 MJ N $\mathrm{m}^{-3}$ ) and low nitrogen concentration. ${ }^{92}$ In that regard, choosing between air and oxygen as a gasifying agent will be highly dependent on the application of the final product as well as the economical evaluation of the process. Fig. 2 presents all primary and secondary product stream pathways.

Gasification of various feedstocks including waste tyres has shown high potential to produce high-quality syngas, however, typical gasification systems have not been developed efficiently to reduce the substantial amounts of energy required to breakdown the feed material. ${ }^{90}$ Also, one of the most critical gaps is the lack of regulatory framework certainty in some emerging countries and the costs associated with the establishment of gasification facilities remain capital intensive, this 


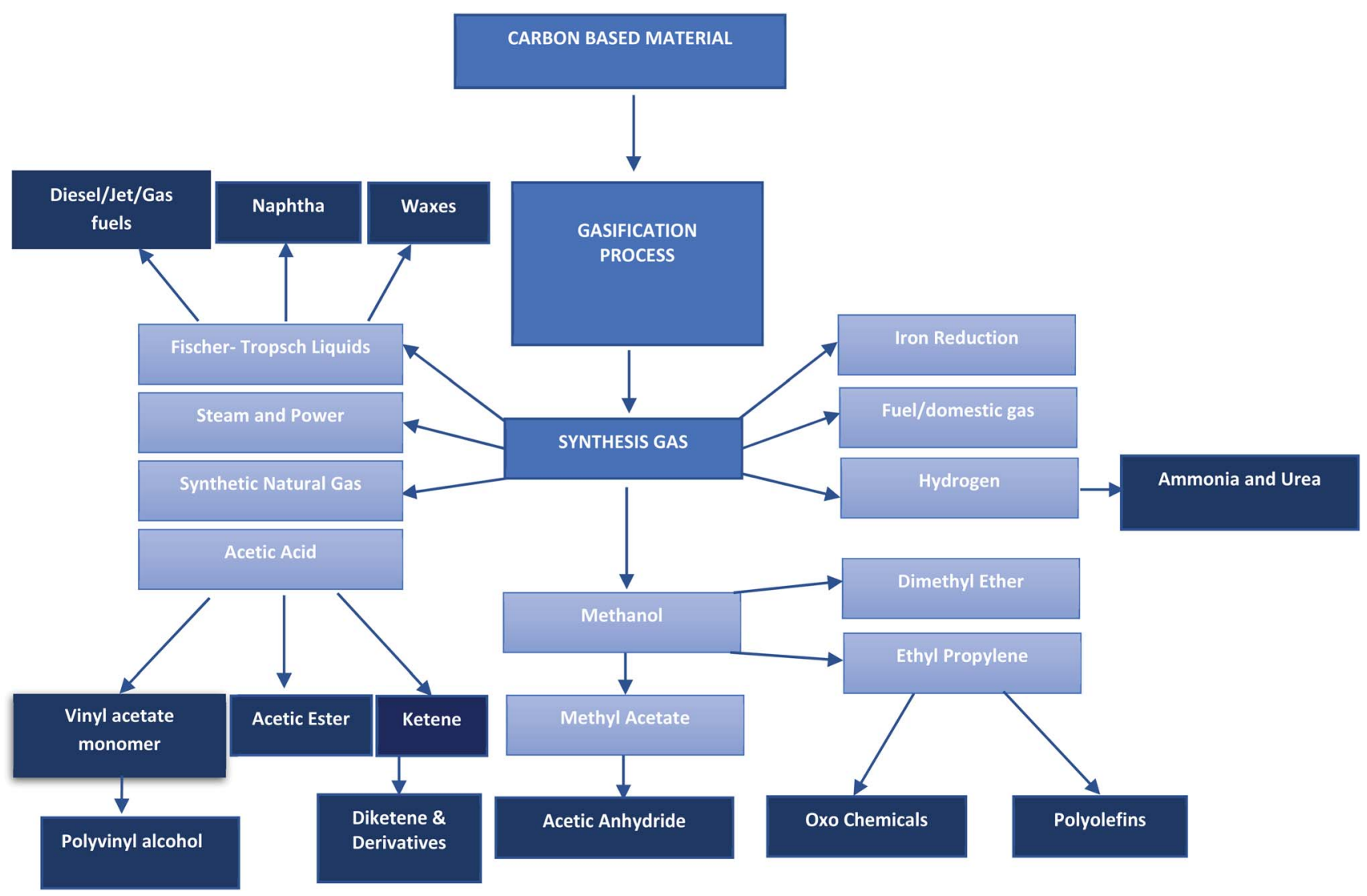

Fig. 2 Gasification process primary and secondary product streams. ${ }^{123}$

is unlikely to change soon. Significant factors such as feed material size, moisture, gasifying agent, equivalent ratio and temperature play a pivotal role in the gasification system and in addition influence product yield. ${ }^{93}$

\subsection{The effect of process parameters}

3.1.1 The effect of reactor design. Literature studies have been conducted that assess the benefits and shortcomings of the fixed and fluidized bed gasifiers. ${ }^{93-95}$

Alauddin et al. ${ }^{96}$ observed several weaknesses in the fixed bed gasifiers. The authors determined that the inconsistent heat and mass transfer between the solids in a fixed bed reactor resulted in excess tar formation, while the fluidized bed promoted adequate contact of solids with the gas. Moreover, the use of bed material further enhances the heat transfer between the solids and gas, allowing various feedstock and or varying sizes to be utilized in the fluidized bed reactor. ${ }^{96}$

3.1.2 The effect of temperature. Unsound process temperature control can affect syngas composition, thus, influencing product quality and in the long run its final applications. According to Le Chatelier's principle, elevated temperatures promote the formation of products under endothermic conditions while reactants are favoured under exothermic conditions, such trends in gasification have been observed by. ${ }^{87,92,96}$ Waste tyres of $3 \mathrm{~mm}$ to $5 \mathrm{~mm}$ were steam gasified at a temperature range of $600{ }^{\circ} \mathrm{C}$ to $800{ }^{\circ} \mathrm{C}$ and produced gas yields from $0.21 \mathrm{~m}^{3}$ $\mathrm{kg}^{-1}$ to $0.76 \mathrm{~m}^{3} \mathrm{~kg}^{-1}$, this is attributed by the temperature's modification of the thermodynamic behaviour of the reactions. However, the heating value was significantly reduced from 9.6 $\mathrm{MJ} \mathrm{m}{ }^{-3}$ to $22.2 \mathrm{MJ} \mathrm{m}^{-3}{ }^{85}$ Furthermore, the authors concluded that using steam in the reactor resulted in improved gas yields when compared to other gasifying agents. ${ }^{97}$ This phenomenon can be justified by the fact that when steam is used as a gasification agent, the process tends to yield a product gas containing more $\mathrm{H}_{2}$ per unit of carbon, resulting in a higher $\mathrm{H} / \mathrm{C}$ ratio and the formation of hydrocarbons. ${ }^{92}$

3.1.3 The effect of moisture content. Literature surveys have shown that reducing moisture content in the feed material promotes increased energy efficiency and improve syngas quality ${ }^{39,92,98}$ Basu further emphasized that the presence of minimal moisture in the material results in improved heat recoveries in the product gas. ${ }^{92}$ Syngas has several domestic and industrial applications, it can be utilized to produce electricity in gas engines or turbines, utilized as a source of heat, used in the manufacturing of fuels and chemicals, and utilized in a catalytic process to produce speciality products..$^{99,100}$

3.1.4 The effect of gasifying agent. Lv et al. ${ }^{101}$ investigated the effect of air-steam biomass gasification in a fluidised bed reactor. The authors concluded that purging in steam to biomass gasification enhances gas quality, in contrast, excessive steam lowers the gasification temperature and reduces gas quality. Parallel work was conducted by Gonzalez et al. ${ }^{102}$ to 


\section{Gasification technology research and development from 1990 to 2021}

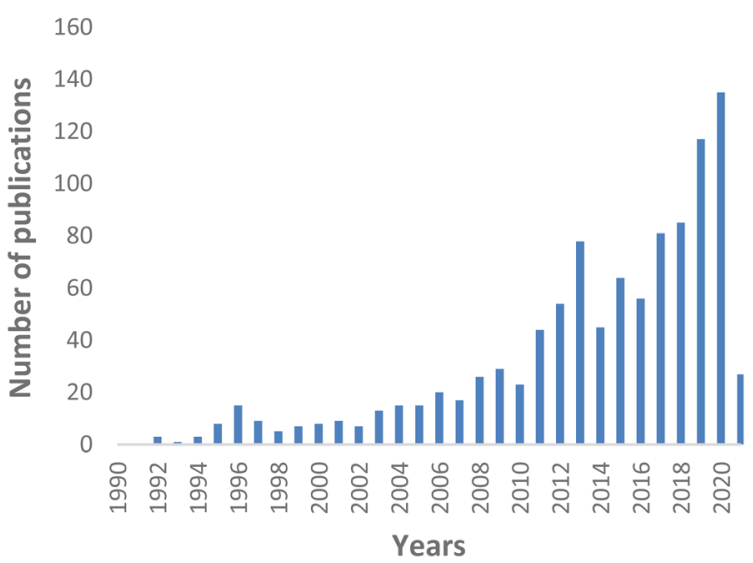

Fig. 3 Gasification technology research and development trends: data extracted from Scopus and science direct search engines, 30 December 2020.

compare the effect of steam and $\mathrm{CO}_{2}$ when utilized as a gasifying agent. The results showed that activated carbon yielded from steam gasification had greater permeability and surface area as compared to those produced using $\mathrm{CO}_{2}$. Moreover, Karatas et $a .^{103}$ gasified waste tyres while employing varying gasification gases such as air and $\mathrm{CO}_{2}$; air and steam and steam alone in a bubbling fluidized bed gasifier. As a result, the authors observed the heating values of air and $\mathrm{CO}_{2}$, air and steam and steam to be $9.59,7.34$ and $15.21 \mathrm{MJ} \mathrm{N} \mathrm{m}^{-3}$ respectively. Lastly, in two distinctive work where the author utilized steam and air as gasifying agents. Karatas ${ }^{\mathbf{1 0 4}}$ realized that steam gasification produced gas with greater $\mathrm{H}_{2}$ content (55-57\%) and LHV (30-37 $\mathrm{MJ} \mathrm{kg}^{-1}$ ), while the inverse can be said about air, a low hydrogen content (15-20\%) and LHV (4-7 $\mathrm{MJ} \mathrm{kg}^{-1}$ ) we obtained during air gasification. The results observed above from different authors prove that steam gasification is favourable to the following gas properties (i) quality, (ii) heating values and, (iii) $\mathrm{H}_{2}$ content. Furthermore, the permeability and surface area of activated carbons produced from steam gasification were significantly improved.

3.1.5 The effect of particle size. Lee and $\mathrm{Kim}^{105}$ gasified waste tyres in a laboratory sized thermo-balance reactor using air as a gasifying agent with a varying particle size range of 0.025 to $0.1 \mathrm{~cm}$. The authors concluded that tyre gasification rate was not dependent on particle size. On the contrary, pulverized tyres were gasified in a laboratory-scale fluidized bed gasifier air at a temperature ranging from $350{ }^{\circ} \mathrm{C}$ to $900{ }^{\circ} \mathrm{C} .{ }^{106}$ The authors determined that the equivalence ratio, tyre feed rate and particle size affect the gasification final product composition and yield, the bed temperature, and the heating value.

\subsection{Research and developments in gasification}

Research and development trends show that a substantial amount of research studies have been directed towards the advancement of the gasification system. In 1801, the water-gas shift reaction was explored by Fourcroy, ${ }^{11}$ subsequently, in 1861 the first gasifier unit, the Siemens gasifier, was installed and operated successfully. ${ }^{107}$ This led to the first commercial gasifier that operated predominantly for solid fuels and later advancements to process various fuels were explored. In the latter years, the gasifier played a critical part in the development of industrial power and heat applications up till the end of the 1920s. ${ }^{95}$ World War II also contributed immensely to the mass manufacturing of compact gasifiers between 1920 to $1940 .^{4}$ During this period, syngas was utilized to power commercial vehicles, used for domestic lighting and cooking, applied in agricultural and industrial machines and other various sectors. ${ }^{92,95}$ However, towards the end of the war, the discovery of copious amounts of fossil fuel in the Middle East became evident, thus, ending the reliance and the era of compact gasifiers. Nevertheless, research into improving the gasification systems continued resulting in the ground-breaking establishment of a continuous gasification system by Carl Linde in 1920 . The fluidized bed and pressurized moving bed gasifiers were developed in 1926 and 1931 respectively. ${ }^{107}$ The energy crisis experienced during the 1970s ignited renewed interests in the gasification processes. The technology yet again offered an alternative and reliable source of energy especially for growing industries in emerging countries that could not keep up with the burden of increased costs of petroleum in the world market whilst possessing rich resources of biomass. Developing countries like the Philippines, Brazil, Indonesia, and India also introduced gasifier application programs based on locally developed technologies. ${ }^{95}$

The Scopus and Science Direct databases were used to collect all the literature that was ultimately used for comparison of the thermochemical processes. From a research point of view, an assessment into the growth, development and trends of the gasification system during the past three decades is shown in

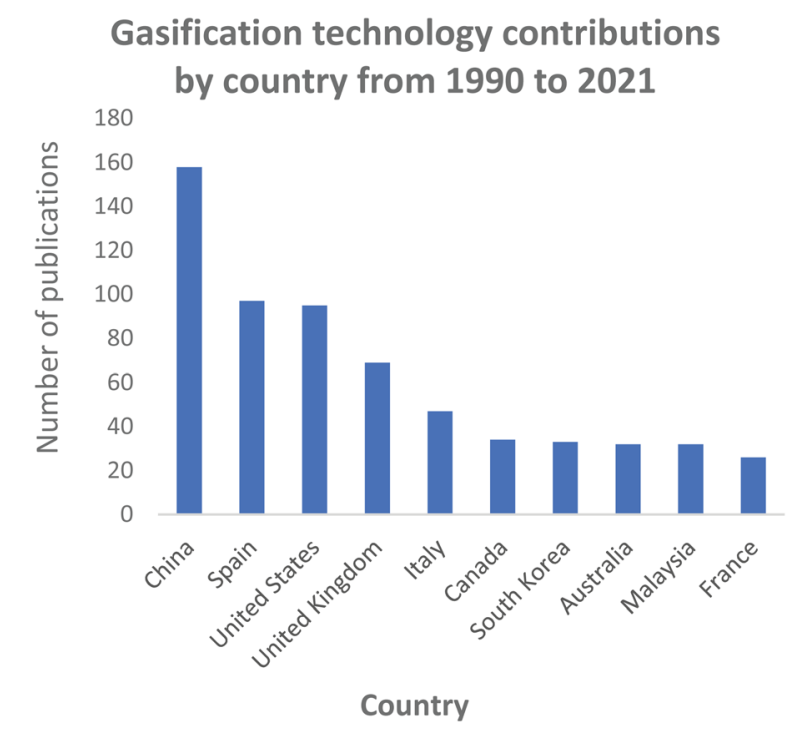

Fig. 4 Gasification process research and development contributions by country: data extracted from Scopus and science direct search engines, 30 December 2020. 
Fig. 3. Amid this period, researchers were starting to critically look at the benefits such as energy, heat and chemical recovery potentials that the gasification process can offer to the growing energy demand, fossil fuel depletion crisis as well as the adverse climate change effects caused by fossil fuels. The various fixed bed reactors (downdraft, updraft, and cross draft); fluidized bed reactors (bubbling bed and circulating bed) and continuous gasification reactors are now well researched, understood and documented in literature. ${ }^{95}$

In Fig. 3, a generally growing interest in gasification research is evident. The increase is immensely contributed by (i) the mass availability of various feedstock material, including waste materials; (ii) the well-defined operating parameters; (iii) the well-understood types of gasification reactors; (iv) the vast domestic, commercial and industrial final application capabilities, and (v) the use of catalysts to develop the process and/or the final generated products. During the 2014-2016 period, inconclusive research attention is noticeable for the gasification field. However, this phenomenon is followed by a sharp increase in research interest due to the Chinese Government's investment in Clean Coal Technology Programs as part of its National Energy Plan. ${ }^{108}$ This is further demonstrated by Fig. 4 which highlights the large contribution and investment that China has made towards gasification. Records show that China has the highest number of gasification facilities that are mostly being operated at industrial and commercial scale. ${ }^{108}$ The year 2020 sparked the largest interest in gasification compared to the past three decades, with research records showing about 135 publications on the gasification process. To date in the year 2021, 27 gasification publications have already been produced thus, presenting a mounting interest in gasification research and advancements. This can be perceived as a significant step that has contributed towards the alleviation of the high dependency on conventional fossil fuels.

In Fig. 4, the top 10 countries that have made significant progress in gasification technology are shown. China, Spain and the USA have contributed significantly into the continuous advancement of the gasification process utilizing a diversity of feedstocks, for instance; waste tyres and waste rubbers, assorted municipal waste, biomass and coal. Countries such as India, China, and most of Southeast Asia share a common trait of high fossil fuel prices due to little or zero fossil fuel reserves. However, they have large reserves of low-grade coal creating a robust market for coal-derived natural gas facilities. On the contrary, coal gasification for power generation has been regressing in the USA, with many of the planned projects being abandoned. ${ }^{109}$ In North America, the materialization of plentiful and affordable natural gas has resulted in coal gasification to be less attractive and viable. Coal is the primary resource of energy in China, contributing 65\% to the country's energy need. ${ }^{45}$ China has employed a vast range of gasification technologies, even extending its use domestically. An assortment of coals is gasified to produce various products including ammonia, oxo-chemicals, methanol, prolyplene, acetic acid, butanol, octanol, urea, ethylene glycol, syngas, dimethyl ether, and liquified petroleum gas. ${ }^{\mathbf{4 5}}$ Researchers such as Williams, Olazar and Bilboa, shown in Fig. 5, have actively contributed to

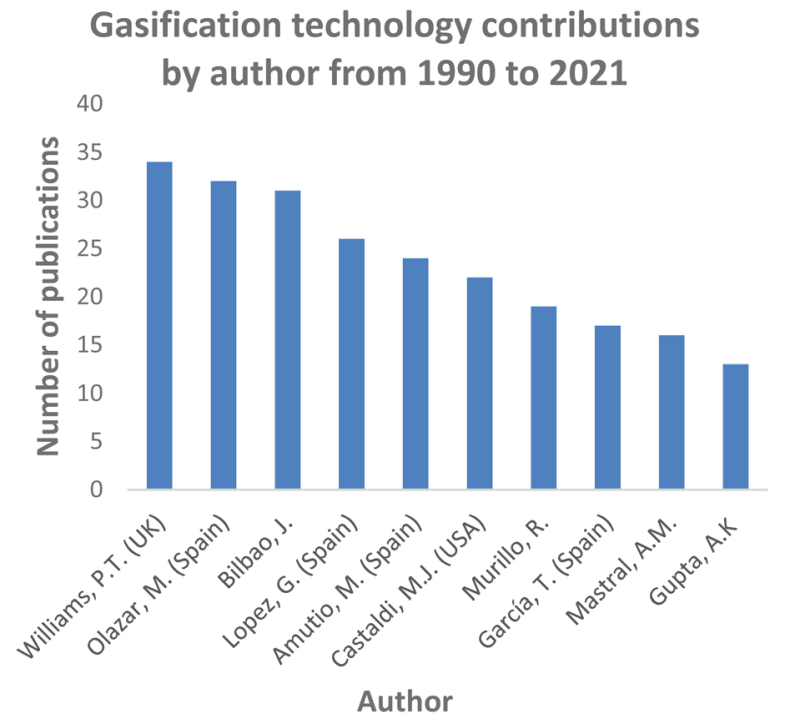

Fig. 5 Gasification technology research and development contributions by authors data extracted from Scopus and science direct search engines, 30 December 2020.

the development of the gasification technology through their published studies and subsequent applications. Williams has fundamentally concentrated on the effect of Nickel (Ni) catalyst on pyrolysis-gasification for hydrogen production and tar removal from biomass feedstock. ${ }^{\mathbf{1 1 0 - 1 1 2}}$ The author also extended his research and collaborations with other researchers to investigate gasification parameters' influence on final products using feedstocks such as waste tyres and plastics. ${ }^{\mathbf{1 1 3 , 1 1 4}}$ Lastly, Williams ${ }^{115}$ together with Elbaba $^{116,117}$ and $\mathrm{Wu},{ }^{114,118}$ pioneered the hydrogen production process through the gasification of waste tyres and plastic waste products. Olazar, Balboa and Lopez collaborated on the further studies and development of the conical spouted bed reactor ${ }^{119-121}$ contributing comprehensively to the understanding of the effect and advantages of mechanical modifications on the conical spouted bed reactor. Moreover, their partnership further expanded on the steam gasification of biomass, plastics and their cogasification subsequently.

\subsection{Case study: gasification facilities}

Numerous prominent gasification facilities that produce a wide range of products from various feedstocks are operational throughout the world. The top 20 gasification plants ranked according to their energy output are presented in Table 3, these plants are of commercial-scale with reported viable technology. Coal remains the predominant feedstock to date, with $65 \%$ of the plants utilizing various coal types. The pearl gas to liquid (GTL), located in Qatar, is the largest facility in term of energy output and employs the most recent cutting-edge technology. South Africa currently has numerous gasification plants in operation, these facilities are discussed in the sections to follow. Sasol Synfuel II in South Africa is the longest standing chemical plant and contributes to about $28 \%$ to South Africa's total petroleum demand ${ }^{\mathbf{1 2 2}}$ and R21 billion or $2 \%$ to the national 
Table 3 Worldwide commercial gasification plants ${ }^{126}$

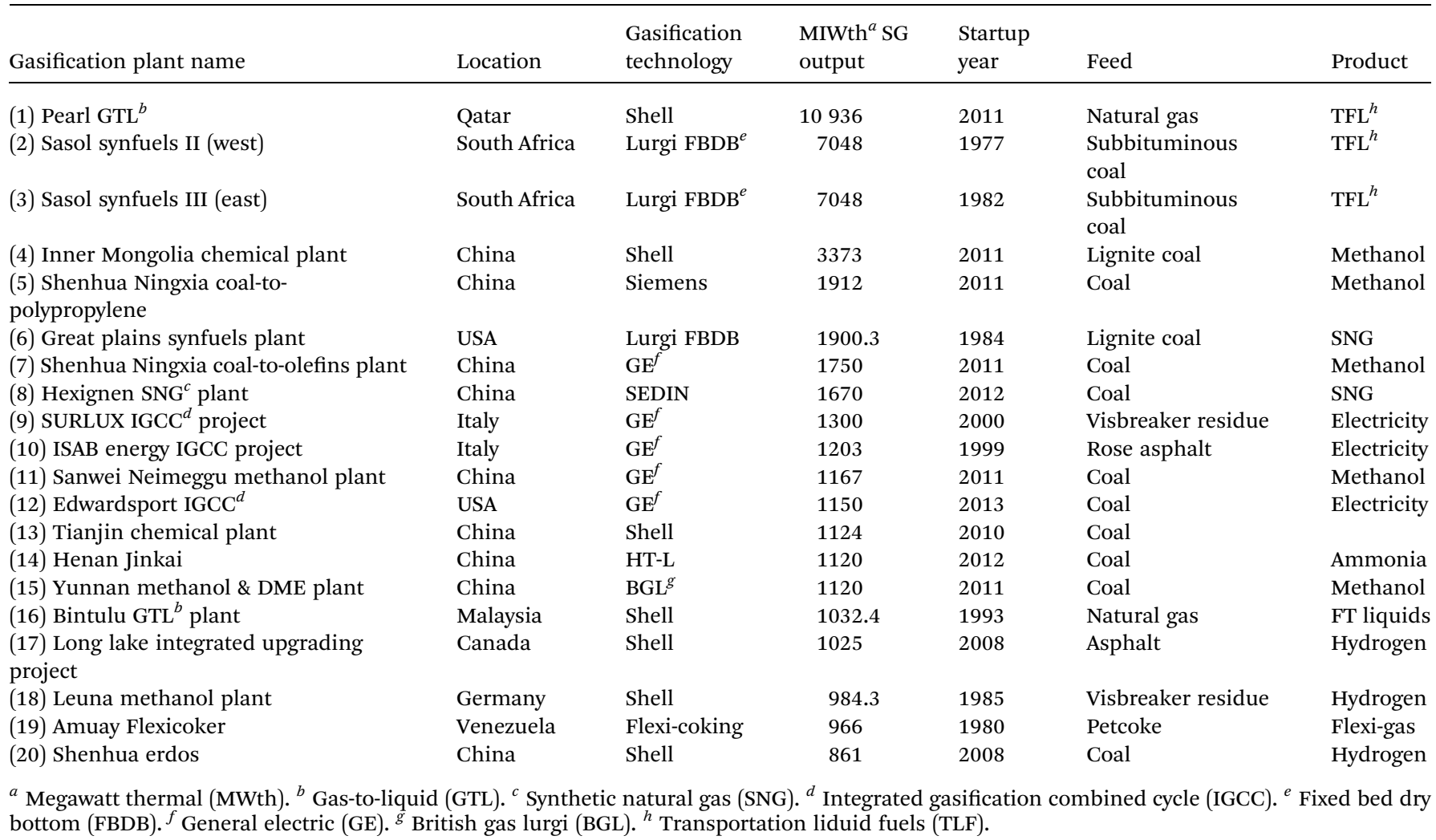

Table 4 Prominent gasification plant in South Africa

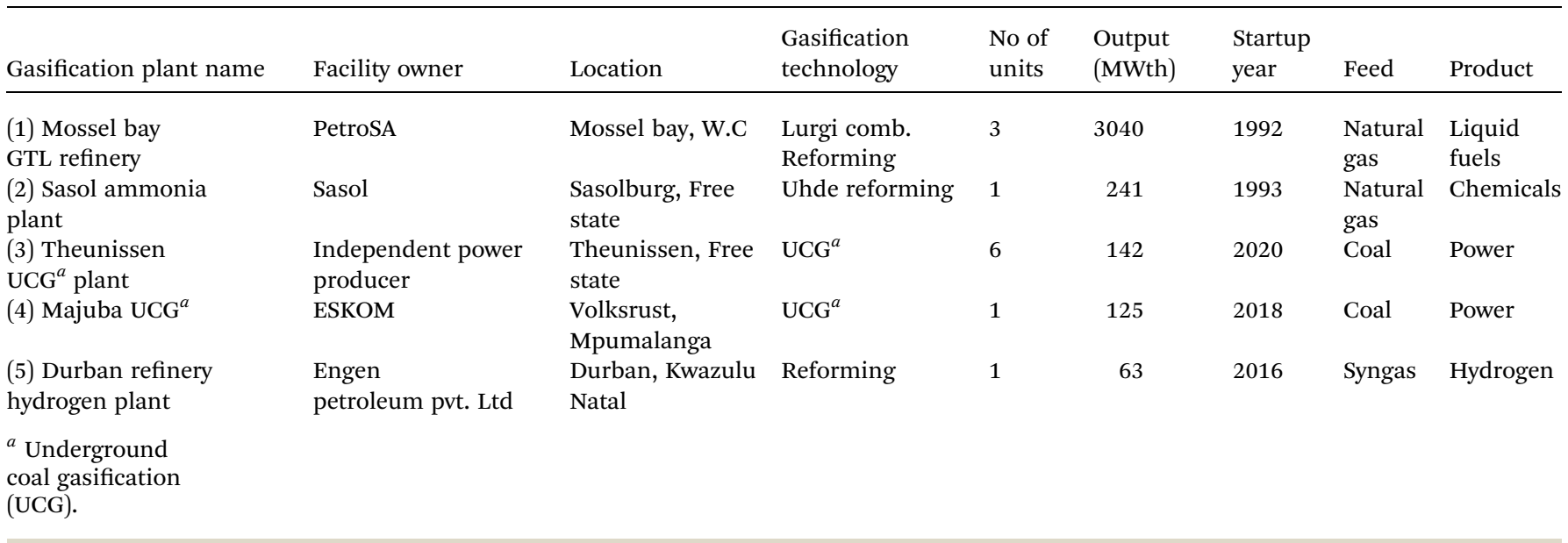

gross domestic product (GDP). ${ }^{1}$ Other gasification facilities currently exist in South Africa, they are of lesser sizes and capacity as compared to Sasol Synfuel West and East, however, these facilities play a significant role in the South African economy. The facilities and their detailed process information are presented in Table 4.

According to Kerester, ${ }^{123}$ approximately $25 \%$ of the world's ammonia and $30 \%$ of the world's methanol is manufactured via the gasification process. The Sasol ammonia plant employs the
Haber-Bosch process in the coal gasification stage of the oil to produce its ammonia. ${ }^{\mathbf{1 2 2}}$ In the latter process, ammonia stripped from the gas liquor is of very high purity which is used in a variety of industrial applications throughout South Africa. The operation produces 30200.00 megaton per annum of ammonia. The Theunissen UCG plant employs the mining technology that unearths previously abandoned coal reserves through a gasification process that converts the coal into syngas. Records show that two-thirds of the earth's coal reserves are not economically 
mineable through conventional mining techniques, ${ }^{\mathbf{1 2 4}}$ UCG offers a workable alternative to extract these deep coal reserves economically. The Theunissen UCG facility is planned for operation in the second quarter of the year $2020 .{ }^{\mathbf{1 2 4}}$ The operation is planned to produce $54 \mathrm{MW}$ of electricity. Eskom presently generates $88 \%$ of its electricity from coal. ${ }^{125}$ This indicates a high dependency on coal for power generation due to its excessive abundance in South Africa. However, Eskom identified the need to employ ecologically friendly technology and the need to fully utilize previously inaccessible coal reserves. This gave birth to the Majuba UCG facility, the $5000 \mathrm{~N} \mathrm{~m}^{3} \mathrm{~h}^{-1}$ pilot plant saw its initiation in January 2007 , however, the facility has been in full operation since 2018 and currently produces 100 MW of electricity. ${ }^{\mathbf{1 2 6}}$ The Durban refinery hydrogen plant is operated by Engen Petroleum Ltd and generates $17000.00 \mathrm{~N} \mathrm{~m}^{3}$ $\mathrm{h}^{-1}$ of hydrogen from syngas by employing reforming technology. ${ }^{126}$

\section{Pyrolysis technology}

Pyrolysis is an endothermic chemical degradation process of organic compounds under an oxygen-deprived environment. The inert environment is achieved by purging inert gases such as $\mathrm{N}_{2}$, Argon or flue gas. The inert gas serves the following purposes; it protects the organic material from oxidation, it meticulously blends the reaction environment, brings equilibrium to the temperature and concentration distribution, assists in discharging volatile pyrolysis products, and it is also a transporter of thermal energy. ${ }^{127}$ The pyrolysis process has been known to follow complex pathways that several chemical reactions can not distinctively defined. However, Li et al. ${ }^{128}$ classified the reactions involved in tyre pyrolysis into three groups, namely; (i) primary pyrolysis reaction that occur at temperature ranges of $250{ }^{\circ} \mathrm{C}$ to $520{ }^{\circ} \mathrm{C}$ where the pyrolysis thermal decomposition process transpires in accordance to a radical chain reaction whereby dehydrogenation advances along with the decomposition of the chief polymer chain; (ii) secondary subsequent-cracking reaction of volatiles occurring at $550{ }^{\circ} \mathrm{C}$ to $800^{\circ} \mathrm{C}$ which promote the development of aromatic and polycyclic aromatic compounds that are attributed to a Diels-Alder cyclization reaction (depicted in Fig. 6), predominantly at elevated temperatures and/or long residence times, and (iii) the pyrolytic carbon black gasifying reaction in the presence of $\mathrm{CO}_{2} / \mathrm{H}_{2} \mathrm{O} / \mathrm{O}_{2}$ gases at temperature ranges of $750{ }^{\circ} \mathrm{C}$ to $1000{ }^{\circ} \mathrm{C}^{47}$ The gaseous segment is mainly composed of the following compounds: $\mathrm{H}_{2}, \mathrm{CO}, \mathrm{CO}_{2}, \mathrm{CH}_{4}, \mathrm{C}_{2}-\mathrm{C}_{5}$ paraffin compounds, $\mathrm{C}_{3}-\mathrm{C}_{5}$ olefin compounds and minute concentrations of sulphur $\left(\mathrm{H}_{2} \mathrm{~S}, \mathrm{SO}_{2}\right)$, carbonyl sulphide (COS), carbon disulphide $\left(\mathrm{CS}_{2}\right)$, and nitrogen $\left(\mathrm{NH}_{3}\right)$ containing compounds. Natural or synthetic rubber decomposition produces $\mathrm{C}_{4}-\mathrm{C}_{5}$ hydrocarbons, while secondary cracking reactions are responsible for forming lighter compounds. Arabiourrutia et al. determined that the employment of catalysts endorse the occurrence of secondary cracking reactions at elevated temperatures, as a result, this yielded more light hydrocarbons compounds from the further decomposition of larger molecules. ${ }^{61}$ The liquid fraction of waste tyre pyrolysis produces
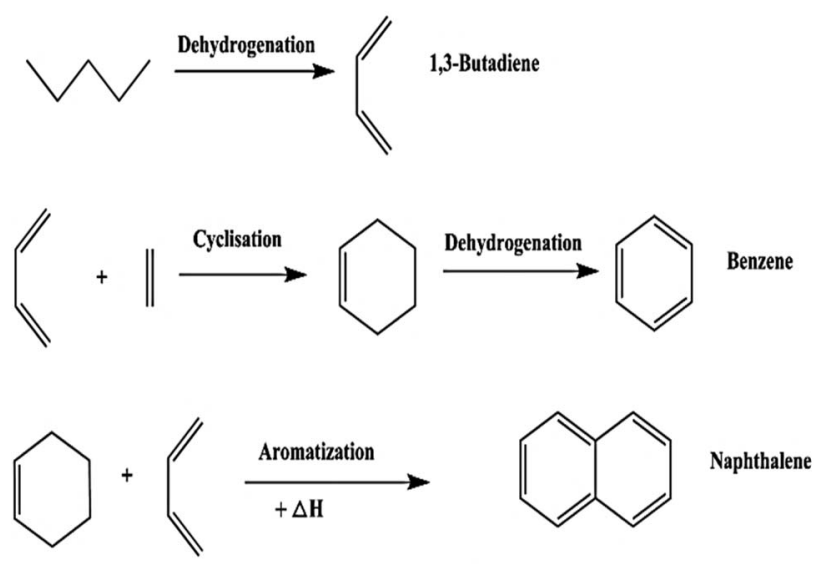

Fig. 6 The Diels-Alder cyclization reaction for the production of polycyclic aromatic hydrocarbons from waste tyres.

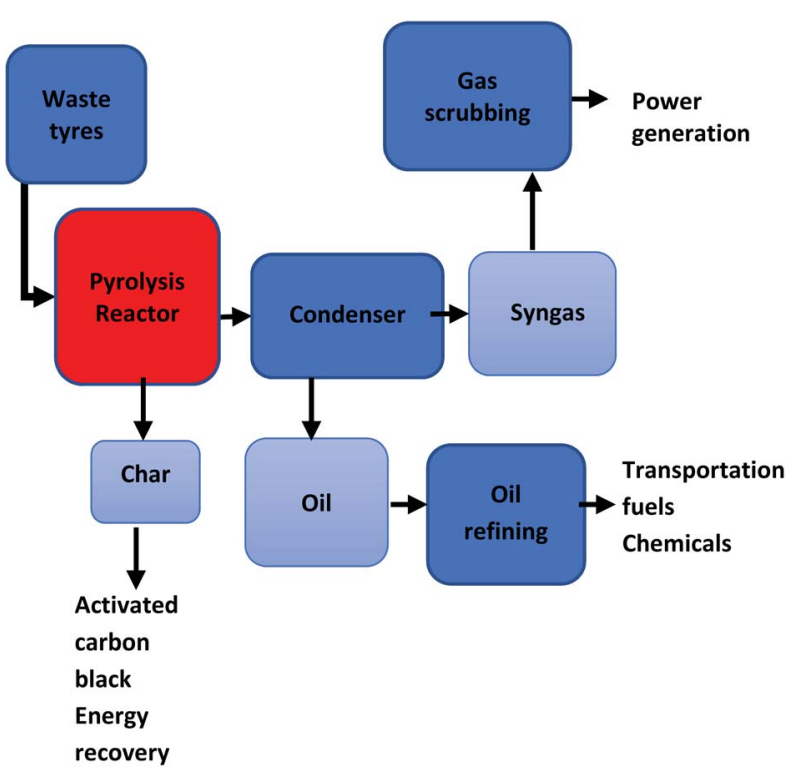

Fig. 7 Waste tyre pyrolysis process pathway.

a mixture of paraffins, olefins and aromatic compounds with a high heating value in the order of $40-45 \mathrm{MJ} \mathrm{kg}^{-1} .^{50}$ Various types of pyrolysis processes have been comprehensively researched over the years and their process conditions are now well defined and understood. ${ }^{39}$ In Fig. 7, a typical pyrolysis process pathway is depicted and reaction 11 (ref. 92) shows the basic pyrolysis reaction. The typical operating temperature employed in pyrolysis ranges between $500{ }^{\circ} \mathrm{C}$ to $800{ }^{\circ} \mathrm{C}$ with gas, liquid, and char being the three primary products. ${ }^{39}$ The composition and percentage yield of each product is highly reliant on the operating conditions, the feed material and the category of the pyrolysis process preferred..$^{129}$

The generation of combustible gas from carbon-based materials is an ancient technique. Egyptians used liquids generated through the pyrolysis process such as tar and pyroligneous acid to preserve their mummies, similarly, the Macedonians attained wood tar from the combustion of biomass in 
pits. ${ }^{130}$ By the end of the 18 th century, methodologies to reclaim and apply condensable pyrolysis products were fairly well established. As a result, brick kilns were employed instead of conventional pits which generally did not capture the gases. ${ }^{\mathbf{1 3 1}}$ In the 19th century, the wood distillation industry capitalized on the by-products generated from charcoal and liquid fuel production to manufacture chemicals such as methanol, acetic acid, and acetone. ${ }^{\mathbf{1 3 0}}$

$$
\mathrm{C}_{n} \mathrm{H}_{m} \mathrm{O}_{p}+\text { heat } \Rightarrow \sum_{\text {liquid }} \mathrm{C}_{a} \mathrm{H}_{b} \mathrm{O}_{c}+\sum_{\text {gas }} \mathrm{C}_{x} \mathrm{H}_{y} \mathrm{O}_{z}+\sum_{\text {solid }} \mathrm{C}
$$

The 20th century saw a rise in the petrochemical industry resulting in the deterioration of the pyrolysis industry. However, the oil crisis brought about renewed attention by shifting focus to alternative technologies. ${ }^{130}$ In the early $1980 \mathrm{~s}$, the fast pyrolysis process was comprehensively studied resulting in its commercialization, ${ }^{\mathbf{1 3 1}}$ during this time, the focused was on identifying the rigorous operating conditions that can maximize product yield. The 1990s saw new and innovative pyrolysis oils upgrading strategies and the beginning of research into alternative products to replace petroleum. The exponential growth in oil prices accompanied by the impact of global warming due to conventional and outdated technologies has created a demand for pyrolysis fuel and char production. The mid-2000s saw the growth in pyrolysis products' possible applications with the latest trend being the application of pyrolytic char for soil enhancement. ${ }^{\mathbf{1 3 2}}$ The potential use of pyrolysis oil directly in internal combustion engines has been explored by several researchers, ${ }^{\mathbf{1 3 3 - 1 3 5}}$ However, its use currently presents several drawbacks such as the high sulphur content, the existence of benzothiazole and alkylated dibenzothiophenes and the presence of dense molecules constituting to high boiling points. ${ }^{136}$

\subsection{The effect of process parameters on the pyrolysis process}

4.1.1 The effect of tyre composition on product yield. The composition of a tyre is influenced by the manufacturing brand, age and tyre category ${ }^{\mathbf{1 3 7 , 1 3 8}}$ which as a result affects the final pyrolysis product distribution and physiochemical characteristics. Kyari et al. ${ }^{\mathbf{1 3 8}}$ pyrolyzed seven different passenger car tyre brands in a fixed bed reactor under the same process conditions. The authors reported distinctions in the gas constituents for the various tyre brands and the gross calorific values for the gas varied between $29.9 \mathrm{MJ} \mathrm{m}^{-3}$ and $42.1 \mathrm{MJ} \mathrm{m}^{-3}$. Also, distinctions in the aromatic composition were observed in the liquid product yields. The conflicting results are attributed to the different blends of raw material that are employed during tyre production. The most common tyre categories are; passenger car tyres, motorcycle tyres and truck tyres, these different tyres exhibit different compositions of natural rubber (NR) and synthetic rubber (SR), the commonly used synthetical rubbers are butyl rubber (BR) and styrene-butadiene rubber (SBR). Truck tyres have been reported to contain twice the quantity of NR and a ratio of $4: 3$ for SR when paralleled with passenger car tyres. ${ }^{47}$ In literature, Ucar, et al. ${ }^{56}$ determined that truck tyres with a NR content of $51 \mathrm{wt} \%$ produced 15.4 vol\% aromatic content, whereas, passenger car tyres with a lesser NR content of $35 \mathrm{wt} \%$ yielded a higher aromatic content of $41.5 \mathrm{vol} \%$. Consequently, passenger car tyres are inclined to chemical production due to their greater aromatic concentration, meanwhile, truck tyres are likely to be suitable in the production of automobile fuel due to their lower sulphur concentration. ${ }^{139}$

4.1.2 The effect of temperature on product yield. One of the main variables that affect the pyrolysis process and product distribution is temperature. ${ }^{47}$ Laresgoiti, M. F. et al. ${ }^{\mathbf{1 4 0}}$ reported an optimum operating pyrolysis process temperature of $500{ }^{\circ} \mathrm{C}$. At lower temperatures, key compounds such as SBR, BR and NR remain in the pyrolytic carbon char. Conversely, an increase in temperature enhances the production of the gas fraction but compromises the oil yield. Islam ${ }^{\mathbf{1 4 1}}$ pyrolyzed motorcycle tyres of $4 \mathrm{~cm}^{3}$ particle size in a fluidized bed reactor at $425{ }^{\circ} \mathrm{C}$. The authors reported gas, liquid and char yields of $9.0 \mathrm{wt} \%$, $47.0 \mathrm{wt} \%$ and $44.0 \%$ wt $\%$ respectively. Similarly, $\operatorname{Kar}^{142}$ obtained gas, oil and char yields of 50.7, 46.2 and $3.0 \mathrm{wt} \%$ respectively when $10 \mathrm{~g}$ of waste tyres were processes in a fixed bed reactor at $375{ }^{\circ} \mathrm{C}$. At the recommended optimum waste tyre pyrolysis of $500{ }^{\circ} \mathrm{C}$, Lopez ${ }^{143}$ performed the pyrolysis of less than $0.1 \mathrm{~cm}$ waste tyre particle size in a conical spouted bed reactor, the author reported $57.0 \mathrm{wt} \%$ oil yield, $4.5 \mathrm{wt} \%$ gas yield and $35 \mathrm{wt} \%$ solid char yield. Likewise, Roy et al. ${ }^{\mathbf{1 4 4}}$ reported significant oil yield of $62.2 \mathrm{wt} \%$ when tyre particle sizes of $0.125 \mathrm{~cm}$ were employed in a vacuum pyrolysis reactor at $500{ }^{\circ} \mathrm{C}$. At higher temperatures of $700{ }^{\circ} \mathrm{C}$, Lucchesi and Maschio ${ }^{\mathbf{1 4 5}}$ pyrolyzed waste tyres in a continuous counter-current fluidized bed reactor under a nitrogen and $\mathrm{CO}_{2}$ environment and obtained gas yields of $26.7 \mathrm{wt} \%$, oil yield of $36.6 \mathrm{wt} \%$ and char yields of 36.7 wt $\%$. Moreover, Zang et al. ${ }^{146}$ processed waste tyres of $0.025-0.085 \mathrm{~cm}$ particle size in a vacuum pyrolysis reactor at $600{ }^{\circ} \mathrm{C}$, the authors reported gas yield of $16.8 \mathrm{wt} \%$, liquid yield of $48.8 \mathrm{wt} \%$ and char yields of $34.8 \mathrm{wt} \%$. From the above literature, it is evident that a direction proportional relationship exists between the gas yield and temperature, also, longer residence times cause the occurrence of secondary reactions in the reactor hot zone that further volatilize the liquid to gas, ultimately resulting in reduced oil yields.

4.1.3 The effect of heating rate on product yield and reactors. In addition to temperature, the heating rate strongly affects pyrolysis process product yields. The heating rate can be used to categorize the pyrolysis process as either slow; fast or flash, and influences the retention time of material in the reaction chamber. ${ }^{\mathbf{1 4 7}}$ The employed heating rate is also associated with the reactor type, and specific reactor types produce higher heating rates. ${ }^{\mathbf{1 4 8}}$ Continuous reactors such as auger reactor (AR), bubbling fluidized bed reactor (BFBR), circulating fluidized bed reactor (CFBR), conical spouted fluidized bed (CSBR), rotary kiln reactor (RKR) are commonly associated with constant temperature values and the temperature gradient remains fixed along the process. The heating rates in these reactors is very high and are strongly influenced by the reactor attributes. ${ }^{47}$ The above observations suggest that low heating 
rates favour the production of solids, while elevated heating rates promote gas production.

4.1.4 The effect of pressure on product yield. Numerous authors have investigated the effect of pressure on pyrolysis product yield and product properties. Buekens reported an increase in oil viscosity with increasing atmospheric pressure. ${ }^{\mathbf{1 4 9}}$ Conversely, Roy et al. ${ }^{\mathbf{1 5 0}}$ and Martinez et al. ${ }^{\mathbf{4 7}}$ determined that pyrolysis under vacuum pressure increased oil yields by reducing the occurrence of secondary reactions. Moreover, the reduction in secondary reactions limited gas accumulation around the char external area, making the char more valued as a carbon adsorbent with increased pore capacity. Lopez et al. ${ }^{143}$ reported similar findings, the authors determined that the positive pressure gradient generated by vacuum resulted in the quicker dispersion of the volatiles into the particle, thus, lowering their retention time and reducing the occurrence of secondary reactions.

4.1.5 The effect of particle size on product yield. P. Parthasarathy et $a{ }^{\mathbf{1 4 7}}$ determined that reduced feed material particle sizes promote efficient conversion and decrease the material and energy needs for the system. On the other hand, larger particle sizes increase carbon black yield, but, compromise oil yield. Osayi et al. ${ }^{151}$ processed waste tyres at a temperature of $600{ }^{\circ} \mathrm{C}$; heating rate of $15^{\circ} \mathrm{C} \mathrm{min}^{-1}$ and various particle sizes of $0.2 \mathrm{~cm}, 0.4 \mathrm{~cm}, 0.6 \mathrm{~cm}, 0.8 \mathrm{~cm}$, and $1 \mathrm{~cm}$. The author reported pyrolytic liquid yield increases from $24.5 \mathrm{wt} \%$ to $34.4 \mathrm{wt} \%$ for $0.2-0.6 \mathrm{~cm}$ particle size; however, a further increase in the particle size to above $0.6 \mathrm{~cm}$ resulted in a decline in oil yield. Generally, a gradual increase in char yield and a decrease in gas yield was noticed within an increase in particle sizes of $0.2-1 \mathrm{~cm}$. Likewise, Islam et al. ${ }^{\mathbf{1 4 1}}$ observed a similar trend when motorcycle tyres were processed in a fixed bed reactor at $475{ }^{\circ} \mathrm{C}$ and particle volume sizes of 2, 4, 6, 8, 10 and 12 $\mathrm{cm}^{3}$. An upsurge in pyrolytic oil yield was observed up to $49 \mathrm{wt} \%$ for the feed size of $4 \mathrm{~cm}^{3}$, subsequently, a gradual reduction in oil yield was noted for larger particle sizes with the lowest yield recorded at $45 \mathrm{wt} \%$ for $12 \mathrm{~cm}^{3}$ particle size. Moreover, the gas yield was observed to decreased while char yield increased with increasing particle size. The increases in oil yields are attributed to the reduced particle feed size which affords more reaction surface of the material resulting in rapid decomposition. The increase in char yield results from the larger material not being entirely decomposed and remaining carbonized in solid form.

4.1.6 The effect of retention time on product yield. Extended retention times have been reported to promote secondary reactions and alter the final product distribution and properties. ${ }^{47}$ Olazar et al. ${ }^{152}$ established that elevated temperatures require rapid tyre retention times and reduced temperatures require extended retention times. Experimental results showing an alike trend were presented by Islam et al., ${ }^{141}$ the authors processed $4 \mathrm{~cm}^{3}$ motorcycle tyres at $475{ }^{\circ} \mathrm{C}$ in a fixed bed reactor at varying retention times of 5, 10, 15 and 20 seconds. Under an increasing vapour retention time of 5-20 seconds, the oil and char yields were reduced while the gas yield increased due to the further volarization of liquid product to secondary permanent gases.

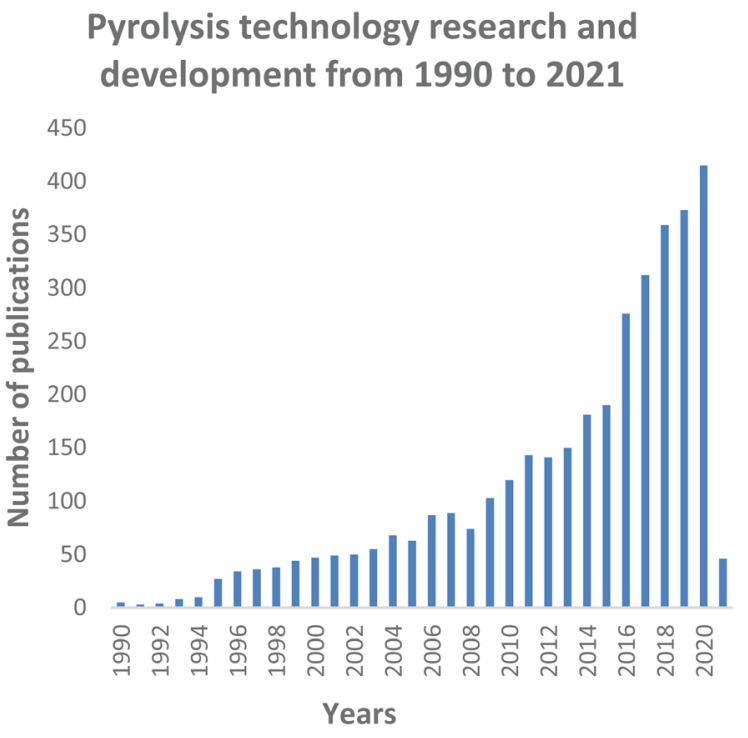

Fig. 8 Pyrolysis technology research and development and trends: data extracted from Scopus and science direct search engines, 30 December 2020.

\section{Pyrolysis technology contributions by author from 1990 to 2021}

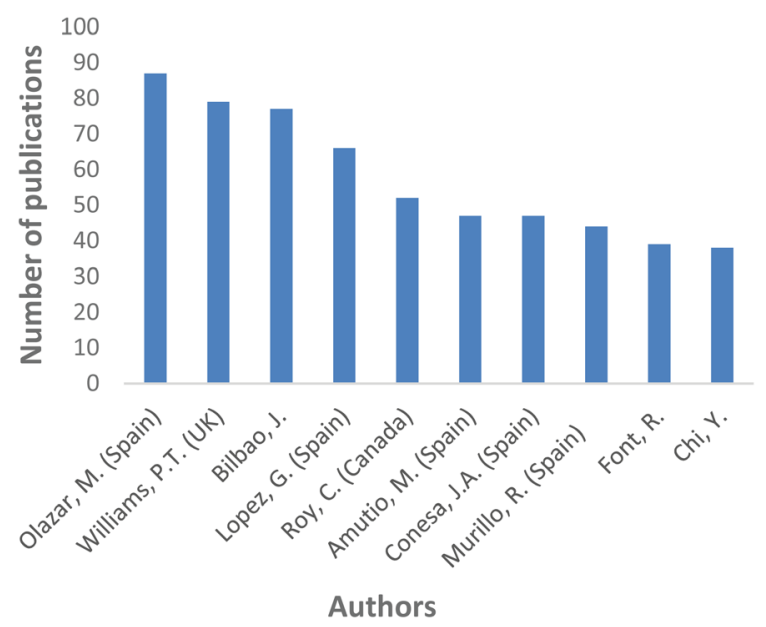

Fig. 9 Pyrolysis technology research and development contributions by authors: data extracted from Scopus and science direct search engines, 30 December 2020.

\subsection{Research and developments of the pyrolysis process}

Pyrolysis technology is constantly evolving with significant research and development still ongoing. The technical expertise on how the technology works is well defined. However, the commercialization of the process is still in its infancy stages. An evaluation of the progress made over the past thirty years of research is mapped out in Fig. 8. Essentially, it can be said that a great deal of research has been channelled towards the pyrolysis technology since the early 1990s. When comparing the trend for all three technologies, namely pyrolysis; gasification and liquefaction. The pyrolysis trend shows a continuously 
growing trend with a few declines in research interest experienced during the years 2005 and 2008. The year 2020 sparked the highest figure in pyrolysis research through the production of 415 research outputs, this depicts a constant increasing research interest in the process as well as the advancements to improve the technology. Several authors have made significant contributions towards the development and well documentation of pyrolysis literature through the research work they have embarked on, shown in Fig. 9. Olazar, Bilboa and Lopez have comprehensively researched various aspects of pyrolysis such as catalytic pyrolysis ${ }^{153-155}$ the co-pyrolysis conversion of plastics, waste tyres and biomass, ${ }^{\mathbf{1 2 1 , 1 5 6 , 1 5 7}}$ reactor design advancements, concentrating on the conical spouted bed reactors ${ }^{\mathbf{1 5 8 - 1 6 0}}$ and the application of pyrolysis products. ${ }^{\mathbf{1 6 1}}$ The authors have also collaborated with Mkhize, Danon and Van Der Gryp ${ }^{\mathbf{1 6 2}}$ to expand research of waste tyre pyrolysis and the conical spouted bed reactor's improved design. Willian P. T. has immensely contributed towards hydrogen production through the pyrolysis of solid waste, ${ }^{117,118,163}$ biomass gasification, ${ }^{164}$ carbon nanotubes, ${ }^{\mathbf{1 6 5}, \mathbf{1 6 6}}$ waste tyre pyrolysis, ${ }^{\mathbf{8 6 - 8 9}}$ and the advancement of thermochemical technologies..$^{63,167,168}$ The author also contributed towards co-pyrolysis using various waste materials ${ }^{169-171}$ and the development of different pyrolysis processes. ${ }^{57,172,173}$ Roy C. contributed significantly towards the pyrolysis of nonconventional materials such as animal meat and bone, ${ }^{\mathbf{1 7 4}}$ tar sands, ${ }^{175}$ bituminous roofing waste materials, ${ }^{176}$ sugarcane bagasse with petroleum residue, ${ }^{177}$ PVC plastics, ${ }^{178-180}$ and electrical cables ${ }^{\mathbf{1 8 1}}$ to produce various products. Also, Roy C. has focused on applying carbon blacks and their comparison with commercial-grade carbon blacks ${ }^{182,183}$

Similarly, with the gasification technology, China has invested immensely into the pyrolysis process as illustrated in Fig. 9. China has been classified as one of the world's rapidly growing economies leading to large-scale urbanization and high waste generating rates. China generated 188.51 million tons of municipal solid waste in 2016 , with $99 \%$ being produced in 214 major cities. ${ }^{\mathbf{1 8 4}}$ The total quantities have been estimated to reach 323 million tons and 480 million tons by 2020 and 2030 respectively. ${ }^{185}$ The number of waste processing facilities in China have increased from 74 in 2008 to 286 in 2017 with plans to increase the capacity by $54 \%$ by $2020 .{ }^{186}$ The waste to energy industry has grown momentously in China with the Chinese government fully endorsing such initiatives and has developed standards to support this industry. During the 1995 to 2000 period, Spain reported the highest MSW generation rates in the EU of 520 and $660 \mathrm{~kg}$ per capita, ${ }^{187}$ composting from 43 to 72 per capita and waste to energy initiatives increased from 70 to 120 per capita. ${ }^{188}$ Regardless of the high MSW generation statistics recorded during this period, landfilling rates declined from 300 to $160 \mathrm{~kg}$ per capita, while upsurges in recycling rose from 50 to $132 \mathrm{~kg}$ per capita, composting from 43 to 72 per capita and waste to energy initiatives increased from 70 to 120 per capita ${ }^{188}$ Spain currently operates 10 waste to energy facilities which have played a critical role in the reduction of waste quantities being diverted for landfilling. ${ }^{187}$

Table 5 Prominent pyrolysis plants in the world

Gasification plant

name

(1)

(1.1) Red arrow, WI

(1.2) Red arrow, WI

(1.3) Ensyn engineering

$\begin{array}{ll}\begin{array}{ll}\text { (3) Bio-alternative } \\ \text { (4) Battelle }\end{array} & \begin{array}{l}\text { USA } \\ \text { Ohio, USA }\end{array} \\ \begin{array}{ll}\text { (5) Empyro } & \text { Hengelo, } \\ \text { Netherlands } & \text { Louisiana, US } \\ \text { (6) Cool planet } & \\ \text { energy system } \\ \text { (7) Anellotech }\end{array} & \text { Texas, USA } \\ \text { (8) Bioliq } & \text { Germany } \\ \text { (9) Proton power } & \text { Tennessee, USA }\end{array}$
Antario

Finland Brazil, Malaysia Canada
University of West

US, Canada, europe,

bed

Circulating fluidised bed

Ultra-pyrolysis:

circulating fluidised bed

Fast pyrolysis in a circulating fluidised bed

Bubbling fluidized bed

Catalytic pyrolysis technology Flash pyrolysis

Catalytic pyrolysis, fluidized bed reactor Fast pyrolysis

Fast pyrolysis
Start-up

year

Capacity

Product

Ref.

Biofuels and

chemicals

Chemicals

203 and 204

1996

$1700 \mathrm{~kg} \mathrm{~h}^{-1}$

Chemicals

203 and 204

$30 \mathrm{~kg} \mathrm{~h}^{-1} \quad$ Oil

203 and 204

2013

$20 \mathrm{~kg} \mathrm{~h}^{-1}$

Oil 65-75 wt\%

203-205

2001

2013

2015

2016

2008

2005

2009

$\begin{array}{lll}400 \mathrm{~kg} \mathrm{~h}^{-1} & \begin{array}{l}\text { Oil 50-75 wt\%, char, } \\ \text { gas }\end{array} & 203 \text { and } 204 \\ 2000 \mathrm{~kg} \mathrm{~h}^{-1} & \begin{array}{l}\text { Char } \\ \text { Transportation fuels }\end{array} & 203 \text { and } 206 \\ 1000 \mathrm{~kg} \mathrm{~h}^{-1} & 207 \\ 5000 \mathrm{~kg} \mathrm{~h}^{-1} & \begin{array}{l}\text { Oil, chemicals, } \\ \text { electricity }\end{array} & 208 \text { and } 209 \\ 10 \mathrm{~kg} \mathrm{~h}^{-1} & \begin{array}{l}\text { Biofuels (fuel and } \\ \text { carbon black) } \\ \text { Chemicals (BTX) } \\ \text { and fuels } \\ \text { Chemical and fuels } \\ \text { Biochar, fuel and } \\ \text { electricity }\end{array} & 210 \\ 500 \mathrm{~kg} \mathrm{~h}^{-1} & 212 \\ & 213 \text { and } 214\end{array}$


Table 6 Various pyrolysis facilities in South Africa

\begin{tabular}{|c|c|c|c|c|c|}
\hline Gasification plant name & Location & $\begin{array}{l}\text { Start-up } \\
\text { year }\end{array}$ & Feed & Product & Ref. \\
\hline (1) IRR manufacturing & Pretoria, Gauteng & 2013 & $1000 \mathrm{~kg} \mathrm{~h}^{-1}$ & Pyrolytic gas, oil and char & 194 \\
\hline (2) Recor & Gauteng South & & & Pyrolytic gas, oil and char & 195 \\
\hline (3) TRIDENT fuels pty ltd & Germiston, Gauteng & & & Crumb rubber, pyrolytic char & 215 \\
\hline (4) Osho SA recycling (pty) ltd & Pretoria, Gauteng & & 40 ton per day & Oil, char and steel wire & 216 \\
\hline (5) Enviroprotek (pty) ltd & Nigel, Gauteng & 2018 & 500 ton per month & Pyrolytic oil, char and steel wire & 196 \\
\hline (6) PPC (de Hoek) & Cape town, Western cape & 2016 & 8000 ton per year & Tyre derived fuel & 191 and 192 \\
\hline (7) Mathe group & Hammasdale, KZN & 2012 & $30-40$ ton per day & Crumb rubber & 193 and 217 \\
\hline (8) Dawhi rubber recycling & Germiston, Gauteng & & 16 ton per day & Crumb rubber & 195 \\
\hline (9) Earth tread pty ltd & Edenvale. Gauteng & 2011 & & Rubber products: paving, roof tiles & 196 \\
\hline (10) Langkloof bricks & Jeffrey's bay, EC & 1999 & $\begin{array}{l}25000-40000 \\
\text { per month }\end{array}$ & Tyre derived fuel: cement kiln & 190 \\
\hline $\begin{array}{l}\text { (11) Tyre energy } \\
\text { extraction pty ltd }\end{array}$ & Coega, EC & 2012 & 42 ton per day & Carbon black & 218 \\
\hline
\end{tabular}

\subsection{Case study: pyrolysis facilities}

Several well-established pyrolysis facilities exist in different sections of the world, the most prominent are located in Canada, the USA, Finland and other countries. Countries like Finland use the vastly available biomass and hydropower to provide heat to households throughout the cold winter months. ${ }^{189}$ Table 5 outlines some commercial and prominent pyrolysis plants that are currently operational worldwide. Biomass is the favoured feedstock of choice due to its abundance and consideration as waste. South Africa has also had numerous successes and failures when it comes to operating pyrolysis facilities currently operating waste tyre pyrolysis or processing plants that produce a variety of end products for various applications are shown in Table 6.

The country currently has numerous successful waste tyre processing facilities. These plants range from modest waste to energy utilization of waste tyres, where facilities such as Langkloof Brickworks and PPC (De Hoek), utilize waste tyres concurrently with coal for their cement manufacturing process. This initiative has substantially reduced energy consumption, minimized $\mathrm{CO}_{2}$ emissions by $50 \%,{ }^{190}$ reduced the usage of coal by $15 \%$ and lowered nitrous oxide emissions. ${ }^{191}$ Other cement manufacturing companies such as AfriSam, La Farge and Natal Portland Cement have implemented the same approach and are realizing the benefits of co-processing coal with waste tyres in their manufacturing process. ${ }^{192}$ Waste tyres exhibit a high heating value than coal and can be a reliable source of fuel for technologies such as combustion, incineration etc., and for industrial applications such as in cement kilns, boilers and smelters. ${ }^{37}$ This technology is fairly modern is South Africa, however, countries such as the USA, Germany and Japan have been employing this technology since the 1970s. ${ }^{28}$ Ambient mechanical grinding processes where whole tyres are fragmented to crumb rubber is another common technique used to reclaim waste tyres. In this technology, mechanical equipment including shredders, rolling mills and granulators disintegrate the tyre at ambient temperature while the steel wires are removed electromagnetically. ${ }^{73}$ Facilities such as Trident Fuels pvt. Ltd, the Mathe Group and Dawhi Rubber Recycling employ this technology. Passenger vehicle and truck tyres are grounded to yield diverse grades of crumb rubber and powders for various applications, such as hard flooring, groundworks for sports

Table 7 The advantages and disadvantages of the different waste tyre processing technologies employed in South Africa

\begin{tabular}{llll}
\hline & Energy recovery & Mechanical grinding & Pyrolysis \\
\hline Advantages & Non-complex system & $\begin{array}{l}\text { Numerous successful markets exist } \\
\text { crumb rubber } \\
\text { Minimal waste generated }\end{array}$ & Higher calorific value products \\
& $\begin{array}{l}\text { System normally has no moving } \\
\text { mechanical parts } \\
\text { Size minimization not required }\end{array}$ & & Energetically self-sufficient \\
& Less environmentally hazardous & $\begin{array}{l}\text { Accommodates the employment of } \\
\text { catalyst to ensure maximum yield of } \\
\text { products and a stable reaction } \\
\text { process } \\
\text { Processes a large variety of feed } \\
\text { material }\end{array}$ \\
Disadvantages & May require gas cleaning system & $\begin{array}{l}\text { Extra energy required for } \\
\text { mechanical moving parts and }\end{array}$ & Higher plant capital costs
\end{tabular}

Ash disposal is a limitation mechanical moving parts and cooling 
grounds and, for the road construction sector. The Mathe Group has reached commercial success in the crumbing of waste tyres in over 20 African countries which include Namibia, Zambia, Botswana, Congo etc. ${ }^{193}$ Lastly, several commercial entities, such as IRR Manufacturing, have employed the pyrolysis of waste tyres at a large-scale capacity of approximately 24 tonne per day while employing a continuous pyrolysis kiln. ${ }^{194}$ The pyrolysis company processes end-of-life tyres, waste wood, and waste polyolefin plastics to generate pyrolytic oil, gas and high-grade carbon char for the global market. Pyrolysis oil produced at 500 litres per hour is utilized in the marine industry. The carbon char produced at $30-380 \mathrm{~kg}$ per hour is briquetted and used as a solid fuel, however, further treatment of the char produces recovered carbon black (rCB) that is by ASTM International Standards approved and applied for use in rubber, plastics, and pigment industries. ${ }^{194}$ Recor-Renewable Energy Corporation, treats a vast diversity of wastes such as metropolitan solid; agricultural; health; abattoir and wood dust to convert them to energy. Moreover, waste tyres are pyrolyzed to produce energy, pyrolytic oil and char, while plastic and waste oils are treated to produce a range of diesel grades. ${ }^{195}$ Lastly, Enviroprotek (pvt.) Ltd, is a small scale waste tyre processing plant that processes $16000 \mathrm{~kg}$ per day of waste tyres in a batch vacuum pyrolysis reactor to produce oil, char and steel wires. ${ }^{196}$ These pyrolysis plants have shown some level of success with the longest running being in operation since 2013, this proves that waste tyre pyrolysis together with the right process economics and profitable product markets can be a viable business. Table 7 compares the advantages and disadvantages of the different waste tyre processing technologies currently employed in South Africa.

\section{Liquefaction technology}

Direct liquefaction involves the breaking down of carbon-based material at elevated temperature and pressure to form a crude liquid product that can be further distilled to form liquid fuels. There are several different methods of production, but the basic process entails the dissolving of carbonaceous material in water or solvent at fairly low temperatures $\left(250-350{ }^{\circ} \mathrm{C}\right)$ and high pressure (5-20 MPa) then subsequently hydrocracking (adding hydrogen over a catalyst). ${ }^{197}$ Liquid yields of $70 \%$ can be achieved with thermal efficiencies of approximately $60-70 \% .{ }^{197} \mathrm{~A}$ schematic pathway of direct coal liquefaction process is shown in Fig. 11. Conversely, indirect liquefaction entails the complete decomposition of carbon-based structures by gasification in the presence of a gasifying agent to form syngas, further treating of the syngas employing the Fischer-Tropsch Process produces liquid hydrocarbon. ${ }^{198}$ A schematic pathway of indirect coal liquefaction processis shown in Fig. 12. Danon et al. ${ }^{50}$ observed that the liquefaction process in rubbers is attributed to the initiation of radical reaction, also, the authors highlighted that the dual bonds in the central polymer are decomposed by the monomer radicals (also known as allylic radicals) developed by $\beta$-scission reactions. These radicals are extremely volatile and experience alkylation formation and cyclization to yield various alkenes and alkyls functional groups. At elevated thermal

\section{Pyrolysis technology contributions by country from 1990 to 2021}

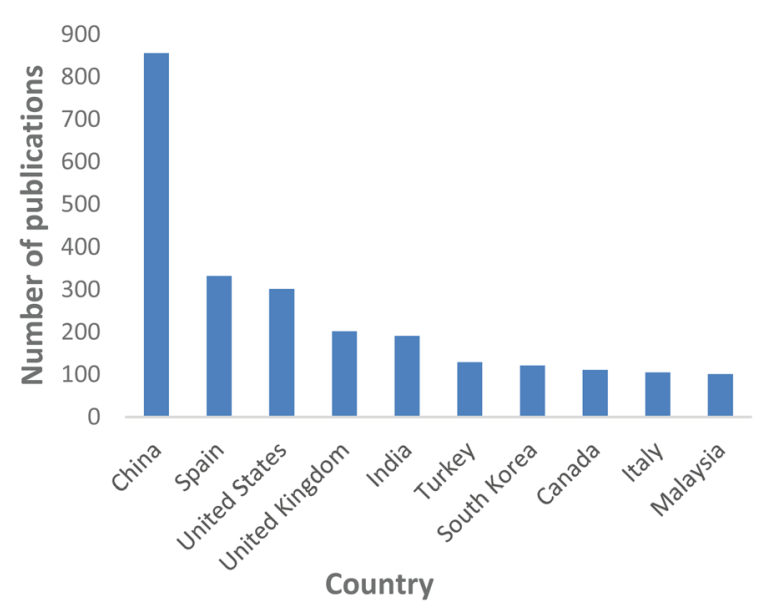

Fig. 10 Pyrolysis technology research and development contributions by country: data extracted from Scopus and science direct search engines, 30 December 2020.

conditions, the disintegration and dehydrogenation reaction mechanism of cyclic compounds from aliphatic compounds results in the development of aromatic hydrocarbons, furthermore, during the hydrolysis reaction, other functional groups such as alcohols, ketones and aldehydes are formed. ${ }^{199}$

Coal is a common substrate for liquefaction in countries deprived of a firm distribution of petroleum such as Germany (during World War II) and South Africa (since the early 1970s). ${ }^{200}$ According to Lumpkin, ${ }^{201}$ direct liquefaction was established by I. G. Bergius in Germany in the 1930s, the

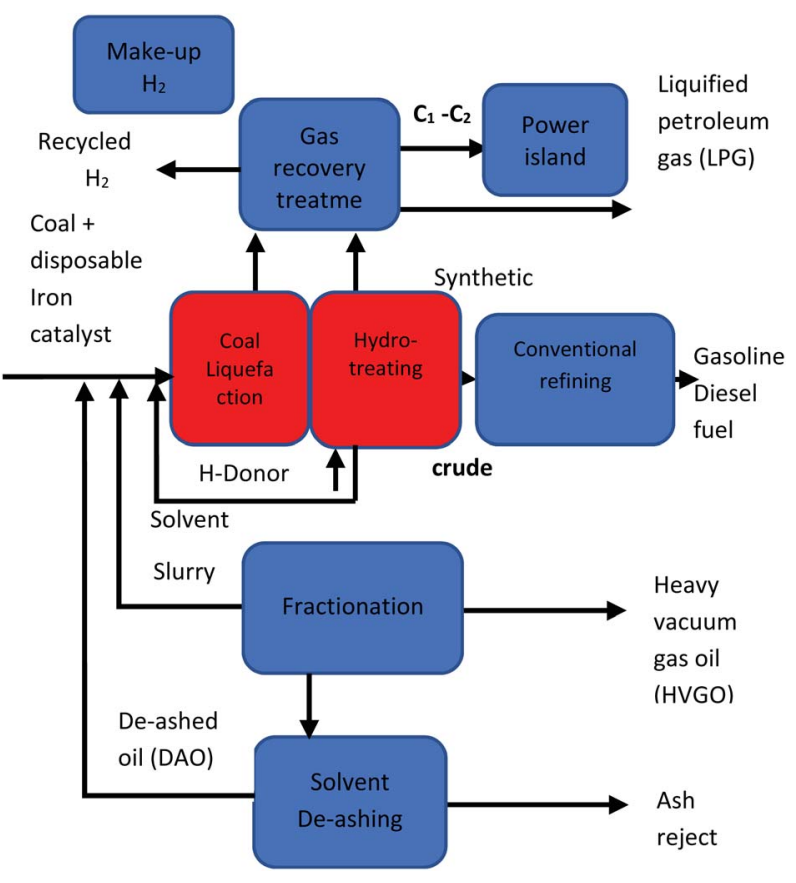

Fig. 11 A schematic pathway of direct coal liquefaction process. ${ }^{241}$ 


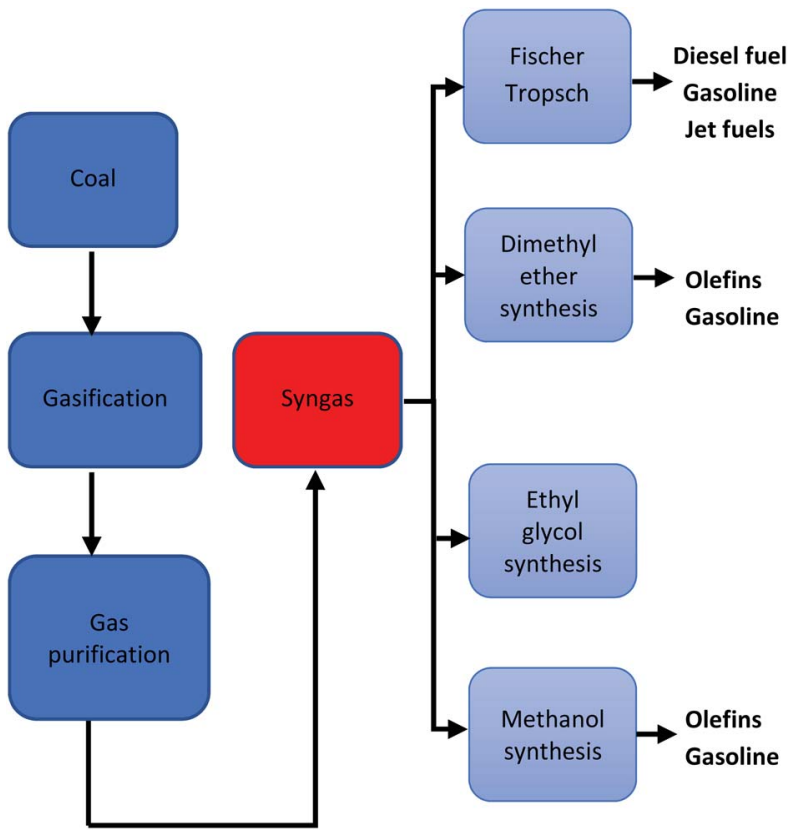

Fig. 12 A schematic pathway of indirect coal liquefaction process. ${ }^{249}$

research included the reacting of coal with $\mathrm{H}_{2}$ at elevated pressures and temperatures. The Bergius process was commercially applied in 1927 by Farben in Germany during the Second World War and supplementary plants were instituted in the 1930s in the former Soviet Union and Czechoslovakia. ${ }^{202}$ Furthermore, small scale plants were operated in Japan and Great Britain. These plants ceased operation due to their economical non-viability. Direct liquefaction research and development progressed after the war and increased considerably amid the oil crunch in the 1970 s. $^{202}$

\subsection{The effect of process parameters}

5.1.1 The effect of raw material and temperature on product yield. Liquefaction product yield is affected by various parameters such as feed material category, temperature, pressure, reaction time, heating rate, solvent type, and catalyst. ${ }^{39}$ Huang et $a .^{219}$ investigated three different feedstocks' liquefaction, namely rice straw, sewage sludge and algae (Spirulina spp.) under the same reaction conditions. The results showed that higher conversion rates are obtainable with Spirulina liquefaction. ${ }^{219}$ However, sewage sludge yielded the greatest biooil yield. The bio-oil hydrocarbon $\left(\mathrm{C}_{17}\right.$ and $\left.\mathrm{C}_{20}\right)$ distribution for sewage sludge and Spirulina were comparable, whereas $\mathrm{C}_{8}$ hydrocarbons were prominent in rice straw. ${ }^{219}$ Moreover, liquefaction of dry municipal refuse, dried sewage, and straw were studied at the University of Manchester Institute of Science and Technology. The findings showed that oil yields of about $35 \mathrm{wt} \%$ were obtainable in the temperature range of $250-400{ }^{\circ} \mathrm{C}$ and 10 MPa pressure. ${ }^{220}$

Brand et al. ${ }^{221}$ researched the impact of reaction temperature on biomass conversion, bio-oil yields, solid fraction, and gas composition. The authors determined that raising the temperature from $280{ }^{\circ} \mathrm{C}$ to $400{ }^{\circ} \mathrm{C}$ resulted in a considerable increase in bio-oil yield from $15.8 \mathrm{wt} \%$ to $59.9 \mathrm{wt} \%$, gas yield increased from $18.2 \%$ to $36.0 \%$, and a significant decline in solid residue from $66.0 \mathrm{wt} \%$ to $1.9 \mathrm{wt} \% .{ }^{171}$ The gas composition was altered with reaction temperature in the following standard ascending trend $\mathrm{CO}>\mathrm{CO}_{2}>\mathrm{C}_{2} \mathrm{H}_{4}>\mathrm{CH}_{4}>\mathrm{C}_{2} \mathrm{H}_{6} \cdot{ }^{222}$ The $\mathrm{CO}_{2}$ and $\mathrm{CO}$ gas production can be attributed to the disintegration of oxygen-based compounds found in the biomass while $\mathrm{CH}_{4}$ is generated from methoxyl groups. Likewise, Jena et al. ${ }^{223}$ and Chan et al. ${ }^{224} \mathrm{ob}-$ tained similar findings and reaction trends for similar experiments. Williams et al..$^{134}$ investigated tyre pyrolysis in a fixed bed reactor at $300{ }^{\circ} \mathrm{C}$ to $720{ }^{\circ} \mathrm{C}$ with heating rates from $1{ }^{\circ} \mathrm{C} \mathrm{min}{ }^{-1}$ to $80^{\circ} \mathrm{C} \min ^{-1}$ and concluded that liquid production was raised with rising heating rates. Likewise, Gonzalez et al. ${ }^{225}$ employed a fixed bed reactor at heating rates ranges of $5{ }^{\circ} \mathrm{C} \mathrm{min}^{-1}$ to $20^{\circ} \mathrm{C} \mathrm{min}^{-1}$ and a temperature of $600{ }^{\circ} \mathrm{C}$. A final liquid yield of $55.4 \%$ was obtained at a heating rate of $15{ }^{\circ} \mathrm{C} \mathrm{min}{ }^{-1}$. This is a consequence of the intensified cracking of at greater heating rates. Quek and Balasubramanian ${ }^{48}$ observed that reduced pressures, raised temperatures and heating rates produced higher oil yields.

5.1.2 The effect of pressure and reaction time on product yield. Brand et al. ${ }^{221}$ investigated the influence of inert $\mathrm{N}_{2}$ pressure on biomass product yield. The authors concluded that the $\mathrm{N}_{2}$ pressure had an insignificant influence on the conversion and the yields of bio-oil, gas and solid liquefaction final products. Conversely, Behrendt et al. ${ }^{226}$ applied Le Chatelier's principle and established that bio-oil yields ascended with increasing pressure. Furthermore, Brand et al. ${ }^{221}$ studied the influence of reaction time on conversion rates and bio-oil yield. The authors increased the reaction time from $\left(t-t_{\mathrm{o}}\right)$ to $60 \mathrm{~min}$ and found that the conversion rate increased from $65.9 \%$ to $89.6 \%$ and bio-oil yield was altered from $37.1 \mathrm{wt} \%$ to $52.0 \mathrm{wt} \%$. Also, additional increases in reaction times to $240 \mathrm{~min}$ improved conversion and oil yield to excesses of $93.6 \mathrm{wt} \%$ and $59.2 \mathrm{wt} \%$ respectively. ${ }^{221}$ Thus, it can be deduced that the interactions between temperature, pressure and heating rate are the most paramount operating factors in the liquefaction process.

5.1.3 The effect of solvent on product yield. The University of Sherbrooke (Quebec, Canada) studies the effect of solvent type on the liquefaction process. Aspen wood and cellulose were treated in aqueous, non-aqueous, creosote, and ethylene glycol media..$^{227}$ Liquid yields of $40-60 \%$ were obtained at $340{ }^{\circ} \mathrm{C}$ in a tubular reactor system. ${ }^{228}$ In addition to water, organics such as methanol, ethanol, acetone etc., have been employed as reaction solvents. ${ }^{36}$ According to Chumpoo et al. ${ }^{228}$ ethanol has proven to be the most efficient solvent for biomass liquefaction when taking into account efficiency, environmental friendliness and reproducible ability. ${ }^{28,229}$

5.1.4 The effect of catalyst on product yield. Catalysts have proven in many thermochemical processes to be one of the most crucial variables that influence the reactions, hence, optimum catalyst selection is paramount. ${ }^{39}$ Researchers have comprehensively researched various catalysts in the liquefaction process, these have included alkali-based catalysts (carbonates and hydroxide forms of $\mathrm{Na}, \mathrm{K})^{230,231}$ Nickel (Ni) in sulphate form, ${ }^{232}$ catalysts on silicon oxide $\left(\mathrm{SiO}_{2}\right) /$ aluminium oxide $\left(\mathrm{Al}_{2} \mathrm{O}_{3}\right)$ support, ${ }^{233}$ sulfides of iron $(\mathrm{Fe})^{233}$ and metal 


\section{Liquefaction technology research and development from 1990 to 2020}

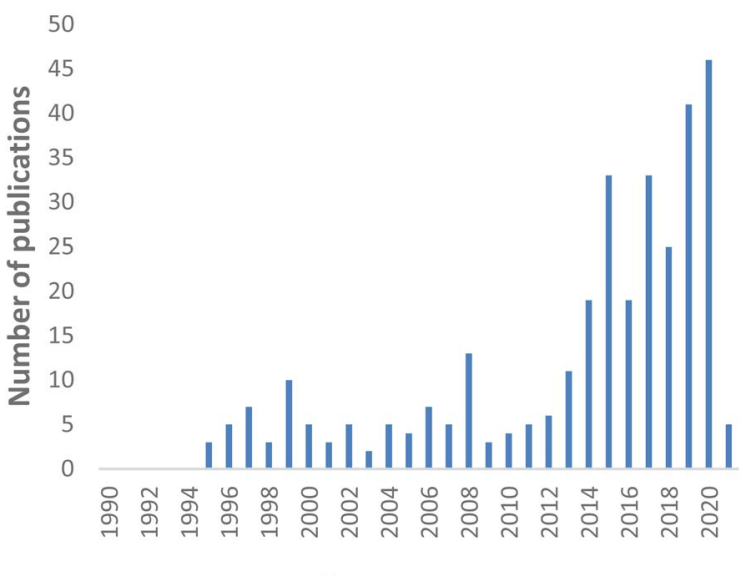

Years

Fig. 13 Liquefaction technology research and development trends: data extracted from Scopus and science direct search engines, 30 December 2020.

catalysts such as rhodium (Ru), molybdenum (Mo) and platinum (Pt) ${ }^{234,235}$ In liquefaction technology, catalysts are known to fundamentally reduce the activation energy, increase liquid yields and improve conversion efficiency by approximately 10$50 \%$ depending on the catalyst in use. ${ }^{236}$

Liquefaction offers numerous benefits over other thermochemical processes. The overall process efficiency is typically higher in liquefaction, the employed process temperature and pressure are lower when paralleled to the gasification process and the produced liquid fuels possess a higher energy density as compared to gas fuels. ${ }^{237}$ Fig. 10 and 11 shows the direct and indirect coal liquefaction process pathway respectively.

\subsection{Research and developments in the liquefaction process}

Direct liquefaction research died down in the mid to late $1980 \mathrm{~s}^{202}$ up until the technology was re-established during the mid-90s as shown in Fig. 13. The 2017 global coal to liquid fuels market was estimated at 3.88 billion USD, ${ }^{238}$ regardless of the decline experienced in 2016 as shown in Fig. 13. In the year 2010, China invested in cleaner coal technologies for fuel supply, thus significantly contributing to the liquefaction technology advancement. The overall liquefaction trend in Fig. 13 shows significant inconclusive results with the development of the technology. However, the liquefaction technology market is expected to expand in the years to come as shown on the growing trend from 2018 to the present. This trend is strongly influenced by the declining dependency on natural gas and crude oil's natural reserves to produce transportation fuels as per the current industry status quo. Several authors have contributed immensely in the research and development of liquefaction technology, as shown in Fig. 14 Anon (1982), ${ }^{239}$ $(1989)^{240}$ played a significant role.
Liquefaction contribution by authors from 1990 to 2021

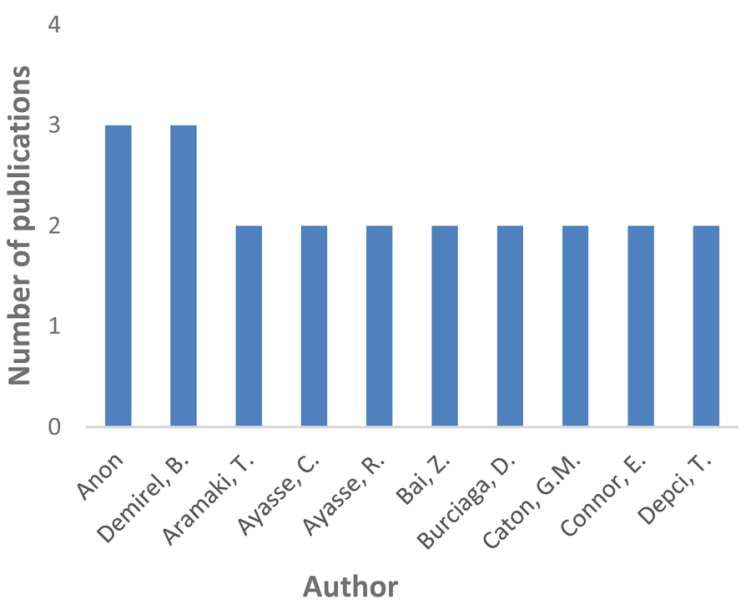

Fig. 14 Gasification process research and development contributions by authors: data extracted from Scopus and science direct search engines, 30 December 2020.

Since the 1980s in the development and application of coal technology in various thermochemical processes, as well as the co-processing of various coals for the production of oils. Mochida reviewed the liquification technology comprehensively in the early 2000s $\mathrm{s}^{\mathbf{2 4 2 , 2 4 3}}$ Demirel (2007) $)^{\mathbf{2 4 4 - 2 4 6}}$ further developed the Rentech coal to liquid fuel technology to commercialization. Lastly, Ayasse and Ayasse (2015), ${ }^{247}(2016)^{248}$ investigated the Fischer-Tropsch process pairing with new gas to liquid technology. The authors reported that pairing these technologies together increased the gas to diesel fuel conversion ratio.

China is the leading country in the global coal to liquid research and development with the highest quantity of actively

\section{Liquefaction countributions by country from 1990 to 2021}

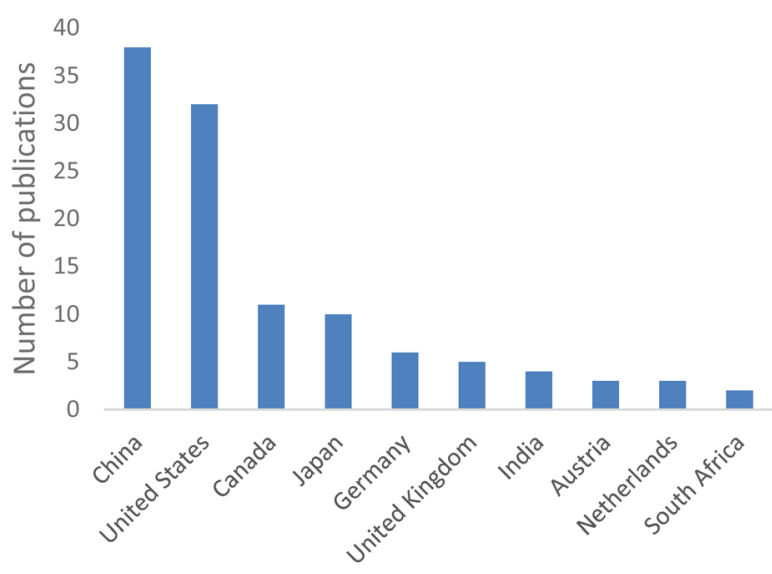

Country

Fig. 15 Gasification process research and development contributions by countries: data extracted from Scopus and science direct search engines, 30 December 2020. 
Table 8 Waste tyre gasification, pyrolysis and liquefaction technology comparison

\begin{tabular}{|c|c|c|c|}
\hline Process & Gasification & Pyrolysis & liquefaction \\
\hline Process definition & $\begin{array}{l}\text { Gasification is a sub-stoichiometric } \\
\text { thermochemical process that } \\
\text { transforms carbon-based feedstock } \\
\text { through the controlled supply of } \\
\text { a gasifying agent into a fuel gas }\end{array}$ & $\begin{array}{l}\text { The thermal degradation of } \\
\text { carbonaceous material in an } \\
\text { oxygen-deprived atmosphere to } \\
\text { maximize thermal decomposition } \\
\text { of solid into gases and condensed } \\
\text { liquid and residual char }\end{array}$ & $\begin{array}{l}\text { Liquefaction is the thermochemical } \\
\text { conversion of an organic solid into } \\
\text { a petroleum-like liquid }\end{array}$ \\
\hline \multicolumn{4}{|l|}{ Process conditions } \\
\hline Reaction environment & $\begin{array}{l}\text { Reducing (oxidant amount lower } \\
\text { than that required by stoichiometric } \\
\text { combustion) }\end{array}$ & Total absence of any oxidant & $\begin{array}{l}\text { Direct liquefaction may involve the } \\
\text { use of solvents such as water and } \\
\text { indirect liquefaction employs the } \\
\text { use of a gasifying agent }\end{array}$ \\
\hline Reactant gas & $\begin{array}{l}\text { Air, pure oxygen, oxygen-enriched } \\
\text { air, steam }\end{array}$ & None & $\begin{array}{l}\text { Solvents and gasifying agents } \\
\text { occasionally employed }\end{array}$ \\
\hline Temperature & $550-1000{ }^{\circ} \mathrm{C}$ & 500 and $800{ }^{\circ} \mathrm{C}$ & $250-350{ }^{\circ} \mathrm{C}$ \\
\hline Pressure & Atmospheric & Slightly above atmospheric pressure & $5-20 \mathrm{MPa}$ \\
\hline \multicolumn{4}{|l|}{ Process outputs } \\
\hline Gas product & $\mathrm{CO}, \mathrm{H}_{2}, \mathrm{CO}_{2}, \mathrm{H}_{2} \mathrm{O}, \mathrm{CH}_{4}$ & $\mathrm{CO}, \mathrm{H}_{2}, \mathrm{CH}_{4}$, paraffins, olefins & $\mathrm{CO}, \mathrm{H}_{2}, \mathrm{CH}_{4}$, paraffins, olefins \\
\hline Liquid product & $\begin{array}{l}\text { Gasification generates small } \\
\text { amounts of oil due to thermal } \\
\text { cracking and steam reforming } \\
\text { reactions at elevated temperatures, } \\
\text { however, a condensable fraction of } \\
\text { tar and soot is generated }\end{array}$ & $\begin{array}{l}\text { Pyrolysis produces oil that has } \\
\text { properties identical to diesel and } \\
\text { can be employed as fuel. It contains } \\
\text { a high aromatic content, thus can } \\
\text { function as an industrial chemical } \\
\text { feedstock }\end{array}$ & $\begin{array}{l}\text { Liquefaction produces a liquid } \\
\text { product comprising of viscous } \\
\text { molecular compounds with } \\
\text { properties comparable, but not } \\
\text { alike, to those of petroleum-based } \\
\text { fuels }\end{array}$ \\
\hline Solid product & $\begin{array}{l}\text { Bottom ash is often the residual } \\
\text { product that can be directly utilized } \\
\text { as backfilling material for road } \\
\text { construction. Upon further } \\
\text { upgrading, the char has the } \\
\text { potential for activated carbon } \\
\text { production }\end{array}$ & $\begin{array}{l}\text { The pyrolysis char has a high } \\
\text { carbon content and can utilized } \\
\text { fuel. Upon further treatment, the } \\
\text { char can be utilized for the } \\
\text { manufacturing of carbon black, } \\
\text { activated carbon and in similar } \\
\text { industries }\end{array}$ & \\
\hline Pollutant & $\begin{array}{l}\mathrm{H}_{2} \mathrm{~S}, \mathrm{HCl}, \mathrm{COS}, \mathrm{NH}_{3}, \mathrm{HCN}, \text { tar, } \\
\text { alkali, particulate matter }\end{array}$ & $\begin{array}{l}\mathrm{H}_{2} \mathrm{~S}, \mathrm{HCl}, \mathrm{NH}_{3}, \mathrm{HCN} \text {, tar, particulate } \\
\text { matter }\end{array}$ & $\mathrm{SO}_{x}, \mathrm{NO}_{x}, \mathrm{CO}$ \\
\hline
\end{tabular}

operating facilities, eight plants on record ${ }^{238}$ and the largest number of publications as shown in Fig. 15. In 2017, China unveiled several indirect and direct coal gasification and liquefaction projects. The Chinese government is keenly investing in manufacturing synthetic fuels from coal to reduce its reliance on imported petroleum. ${ }^{238}$ South Africa, India and Indonesia are some of the developing countries that have made advancements in the liquefaction technology. South Africa developed the coal-toliquid technology in the 1950s during an oil deficiency period, the technology currently plays an integral part in the South African economy. ${ }^{131}$ The technology is considered economically viable in countries which have vast coal resources. ${ }^{\mathbf{1 3 2}}$

The overall waste tyre gasification, pyrolysis and liquefaction technology comparison is depicted in Table 8.

\section{Conclusion}

From literature, it is evident that thermochemical conversion processes have over the previous decades played an essential role in the;

- diverting of certain waste streams from landfill sites,

- production of value-added final products that can be a source of fuel, energy and chemicals and,
- in the creation of green jobs from the establishment and operation of thermochemical PGL facilities.

In addition, abundant literature has been developed to define the operating factors such as temperature, pressure, particle size, heating rate, the use of solvent, types of reaction environment, reactor configuration and the use of catalysts which ultimately influence product yield and quality. The authors established that general agreements can be found with some of these factors but no overall relationship can be deduced.

The following highlights were realized from the study:

- There has been growing world interest in pyrolysis and gasification technologies since the early 1990s to the present times, however, interest in liquefaction technology only commenced during the mid-1990s. Moreover, the trends of PGL research and development show a generally increasing percentage interest in the technologies from 1990 to 2021.

- Many authors have identified a vast range of waste feedstocks, such as; waste tyres, biomass, plastics, food waste, microalgae and animal manure for use in PGL processes. The final products obtained from these waste materials have yielded promising application benefits that can be employed in PGL conversion processes. 
- China has invested immensely into waste to energy initiatives and has demonstrated the vast applications for waste derived products. The country's high population rates has contributed to the generation of large quantities of waste material, which is greatly used in PGL conversion technologies. Furthermore, the country has capitalized in its high abundance of low grade coal which is used in PGL processes.

- PGL technologies employing waste tyres as a feedstock have demonstrated the potential of producing high-end values products in their crude form or refined form, that can be applied in industries such as the energy sector, chemical industry, petroleum industry, rubber manufacturing, solid carbon based industries, pigments and dyes industries, agricultural sector etc. However, shortcomings such as (i) the capital intensive costs associated with the establishment of PGL facilities; (ii) the lack of well established and regulated markets for PGL end-products; and (iii) the necessity for further treatment steps for the purpose of enhancing PGL end-products to commercial products alike still exist.

Some of the most critical gaps that were ascertained during this study are:

- Generally, African countries seem to show less interest in the investing into waste to energy initiatives. However, South Africa is steadily showing a keen interest in the development of PGL technologies and has developed various end-product streams for the attained products. Moreover, the country is encouraging the use of waste material as feedstock during these processes.

- The lack of regulatory framework certainty in some emerging countries has proven to be a hinderance in the further development of PGL processes.

\section{Conflicts of interest}

There are no conflicts to declare.

\section{Acknowledgements}

The authors are grateful to the National Research Foundation (NRF) the University of Johannesburg's Global Excellence and Stature scholarship for financial support. The authors also acknowledge the University of Johannesburg, the Botswana International University of Science and Technology and the University of South Africa for supporting this work.

\section{References}

1 World Coal Institute, Coal: Liquid Fuels, 2009, https:// www.worldcoal.org/file_validate.php? file $=$ coal_liquid_fuels_report(03_06_2009).pdf.

2 EIA. U.S. Energy Information Administration, Energy Outlook Data Browser, 2020, accessed June 1, 2020, http:// www.eia.gov/.

3 ONU, World Population Prospects 2019, 2019, http:// www.ncbi.nlm.nih.gov/pubmed/12283219.
4 World Bank Group, Commodity Markets Outlook. Implications of COVID-19 for Commodities, 2020, DOI: 10.1017/CBO9781107415324.004.

5 Department of Energy, South African Basic Fuel Price, 2020, accessed June 1, 2020, http:/www.energy.gov.za/Files/ Esources/Petroleum/Petroleum_Arch.Html.

6 Norton Rose Fulbright, South Africa Oil prices drop: What will fuel the energy industry post -COVID-19, Norton Rose Fulbright, 2020.

7 C. Zou, Unconventional Petroleum Geology, Elsevier, 2nd edn, 2017, DOI: 10.1016/b978-0-12-812234-1.09001-4.

$8 \mathrm{M} . \mathrm{Hu}, \mathrm{Z}$. Cheng, M. Zhang, et al., Effect of calcite, kaolinite, gypsum, and montmorillonite on huadian oil shale Kerogen pyrolysis, Energy and Fuels, 2014, 28, 1860-1867, DOI: $10.1021 / \mathrm{ef} 4024417$.

9 F. Nie, D. He, J. Guan, K. Zhang, T. Meng and Q. Zhang, The influence of abundant calcium oxide addition on oil sand pyrolysis, Fuel Process. Technol., 2017, 155(155), 216-224, DOI: 10.1016/j.fuproc.2016.06.020.

10 J. Xie, L. Xin, X. Hu, W. Cheng, W. Liu and Z. Wang, Technical application of safety and cleaner production technology by underground coal gasification in China, $J$. Cleaner Prod., 2020, 250, 119487, DOI: 10.1016/ j.jclepro.2019.119487.

11 H. Jiang, M. Wang, Y. Li, L. Jin and H. Hu, Integrated coal pyrolysis with steam reforming of propane to improve tar yield, J. Anal. Appl. Pyrolysis, 2020, 147, 104805, DOI: 10.1016/j.jaap.2020.104805.

12 F. Pinto, J. M. Hidalgo-Herrador, F. Paradela, et al., Coal and waste direct liquefaction, using glycerol, polyethylene waste and waste tyres pyrolysis oil. Optimisation of liquids yield by response surface methodology, J. Cleaner Prod., 2020, 255, 120192, DOI: 10.1016/ j.jclepro.2020.120192.

13 W. M. Lewandowski, K. Januszewicz and W. Kosakowski, Efficiency and proportions of waste tyre pyrolysis products depending on the reactor type-A review, J. Anal. Appl. Pyrolysis, 2019, 140, 25-53, DOI: 10.1016/j.jaap.2019.03.018.

14 G. Zhang, F. Chen, Y. Zhang, et al., Properties and utilization of waste tire pyrolysis oil: A mini review, Fuel Process. Technol., 2021, 211, 106582, DOI: 10.1016/ j.fuproc.2020.106582.

15 A. AlNouss, G. McKay and T. Al-Ansari, Production of syngas via gasification using optimum blends of biomass, J. Cleaner Prod., 2020, 242, 118499, DOI: 10.1016/ j.jclepro.2019.118499.

16 M. N. Uddin, K. Techato, J. Taweekun, et al., An Overview of Recent Developments in Biomass Pyrolysis Technologies, Energies, 2018, 11(11), 3115, DOI: 10.3390/en11113115.

17 A. R. K. Gollakota, N. Kishore and S. Gu, A review on hydrothermal liquefaction of biomass, Renewable Sustainable Energy Rev., 2018, 81, 1378-1392, DOI: 10.1016/j.rser.2017.05.178.

18 X. Liu, K. R. G. Burra, Z. Wang, J. Li, D. Che and A. K. Gupta, Syngas Characteristics from Catalytic Gasification of Polystyrene and Pinewood in CO2 atmosphere, J. Energy Resour. Technol., 2021, 7, 1-24, DOI: 10.1115/1.4049587. 
19 I. M. Maafa, Pyrolysis of Polystyrene Waste: A Review, Polymers, 2021, 13(2), 225, DOI: 10.3390/polym13020225.

20 M. S. Seshasayee and P. E. Savage, Oil from plastic via hydrothermal liquefaction: Production and characterization, Appl. Energy, 2020, 278, 115673, DOI: 10.1016/j.apenergy.2020.115673.

21 J. Liu, D. Wang, C. Yu, et al., A two-step process for energyefficient conversion of food waste via supercritical water gasification: Process design, products analysis, and electricity evaluation, Sci. Total Environ., 2021, 752, 142331, DOI: 10.1016/j.scitotenv.2020.142331.

22 E. O. B. Ogedengbe, J. O. Odeleye, D. R. Enarevba, A. B. Ehinmowo, O. G. Awosanya and A. Director, Recovery of Partial Heat of Pyrolysis from Solar Thermal Collector for Thermochemical Conversion of Food Waste, published online 2021, DOI: 10.1115/1.4049626.

23 W. H. Chen, Y. Y. Lin, H. C. Liu, et al., A comprehensive analysis of food waste derived liquefaction bio-oil properties for industrial application, Appl. Energy, 2019, 237, 283-291, DOI: 10.1016/j.apenergy.2018.12.084.

24 N. Hossain, T. M. I. Mahlia and R. Saidur, Latest development in microalgae-biofuel production with nanoadditives, Biotechnol. Biofuels, 2019, 12(1), 1-16, DOI: 10.1186/s13068-019-1465-0.

25 S. Li, D. Zou, L. Li, et al., Evolution of heavy metals during thermal treatment of manure: A critical review and outlooks, Chemosphere, 2020, 247, 125962, DOI: 10.1016/ j.chemosphere.2020.125962.

$26 \mathrm{~J}$. S. Yadav, Feasibility study on utilisation of clay-waste tyre rubber mix as construction material, Proc. Inst. Civ. Eng.: Constr. Mater., 2020, 1-13, DOI: 10.1680/jcoma.19.00114.

27 M. Mrad and R. El Samra, Waste Tire Management: Lebanon Case Study Waste Tire Management: Lebanon Case Study, J. Waste Manage. Dispos., 2020, 3(1), 1-13.

28 G. Oliveira Neto, L. Chaves, L. Pinto, J. Santana, M. Amorim and M. Rodrigues, Economic, Environmental and Social Benefits of Adoption of Pyrolysis Process of Tires: A Feasible and Ecofriendly Mode to Reduce the Impacts of Scrap Tires in Brazil, Sustainability, 2019, 11(7), 2076, DOI: $10.3390 /$ su11072076.

29 J. Xu, J. Yu, J. Xu, et al., High-value utilization of waste tires: A review with focus on modified carbon black from pyrolysis, Sci. Total Environ., 2020, 742, DOI: 10.1016/ j.scitotenv.2020.140235.

30 S. Oelofse, Industry Waste Management Plan for Tyres, 2020.

31 Crude oil | 1983-2021 Data | 2022-2023 Forecast | Price | Quote | Chart | Historical, accessed January 25, 2021, https://radingeconomics.com/commodity/crude-oil.

32 S. K. Ning, M. C. Hung, Y. H. Chang, H. P. Wan, H. T. Lee and R. F. Shih, Benefit assessment of cost, energy, and environment for biomass pyrolysis oil, J. Cleaner Prod., 2013, 59, 141-149, DOI: 10.1016/j.jclepro.2013.06.042.

33 J. Pilusa, M. Shukla and E. Muzenda, Economic Assessment of Waste Tyres Pyrolysis Technology: A Case study for Gauteng Province, South Africa, Int. J. Res. Chem. Metall. Civ. Eng., 2014, 1(1), 41-49.
34 F. Riedewald, Technological and economical feasibility of a 40 , 000 t /y tyre pyrolysis plant: results of a H2020 SME Phase 1 study, 2016 (March), pp. 1-29.

35 N. Nkosi, E. Muzenda, T. A. Mamvura, M. Belaid and B. Patel, The development of a waste tyre pyrolysis production plant business model for the gauteng region, South Africa, Processes, 2020, 8(7), DOI: 10.3390/pr8070766.

36 E. Muzenda, A Comparative Review of Waste Tyre Pyrolysis, Gasification and Liquefaction (PGL) Processes, in International Conference on Chemical Engineering \& Advanced Computational Technologies, International Conference on Chemical Engineering \& Advanced Computational Technologies, 2014, pp. 1-6.

37 N. Nkosi, Waste tyre management trends and batch pyrolysis studies in Gauteng, South Africa, published online, 2014.

38 Sustainable Org, Waste to Energy: Incineration, gasification and pyrolysis, published online 2019, pp. 179-180. https:// en.wikipedia.org/w/index.

39 P. McKendry, Energy production from biomass (part 3): gasification technologies, Bioresour. Technol., 2002, 83(1), 55-63.

40 V. S. Sikarwar, M. Zhao, P. Clough, et al., An overview of advances in biomass gasification, Energy Environ. Sci., 2016, 10, 2939, DOI: 10.1039/c6ee00935b.

41 A. T. Hoang, T. H. Nguyen and H. P. Nguyen, Scrap tire pyrolysis as a potential strategy for waste management pathway: a review, Energy Sources, Part A, 2020, DOI: 10.1080/15567036.2020.1745336.

42 X. Tang, Z. Chen, J. Liu, et al., Dynamic pyrolysis behaviors, products, and mechanisms of waste rubber and polyurethane bicycle tires, J. Hazard. Mater., 2021, 402, 123516, DOI: 10.1016/j.jhazmat.2020.123516.

43 K. Ding, Z. Zhong, B. Zhang, Z. Song and X. Qian, Pyrolysis characteristics of waste tire in an analytical pyrolyzer coupled with gas chromatography/mass spectrometry, Energy Fuels, 2015, 29(5), 3181-3187, DOI: 10.1021/ acs.energyfuels.5b00247.

44 H. B. Goyal, D. Seal and R. C. Saxena, Bio-fuels from thermochemical conversion of renewable resources: A review, Renewable Sustainable Energy Rev., 2008, 12(2), 504-517, DOI: 10.1016/j.rser.2006.07.014.

45 S. Xiu and A. Shahbazi, Bio-oil production and upgrading research: A review, Renewable Sustainable Energy Rev., 2012, 16(7), 4406-4414, DOI: 10.1016/j.rser.2012.04.028.

46 A. A. Yousefi, A. Ait-Kadi and C. Roy, Effect of used-tirederived pyrolytic oil residue on the properties of polymermodified asphalts, Fuel, 2000, 79, 975-986, DOI: 10.1016/ S0016-2361(99)00216-1.

47 J. D. Martínez, N. Puy, R. Murillo, T. García, M. V. Navarro and A. M. Mastral, Waste tyre pyrolysis - A review, Renewable Sustainable Energy Rev., 2013, 23, 179-213, DOI: 10.1016/j.rser.2013.02.038.

48 A. Quek and R. Balasubramanian, Liquefaction of waste tires by pyrolysis for oil and chemicals - A review, J. Anal. Appl. Pyrolysis, 2013, 101, 1-16, DOI: 10.1016/ j.jaap.2013.02.016. 
49 B. Liu, J. Jiang, B. Chen and S. Yao, Study on purification of pyrolytic oil derived from pilot-scale pyrolysis of waste tires in multilevel reactor, J. Basic Sci. Eng., 2006, 14, 529-534.

50 B. Danon, P. Van Der Gryp, C. E. Schwarz and J. F. Görgens, A review of dipentene ( $\mathrm{dl}$-limonene ) production from waste tire pyrolysis, J. Anal. Appl. Pyrolysis, 2015, 112, 113, DOI: 10.1016/j.jaap.2014.12.025.

51 I. M. Rifiqul, H. Haniu and A. B. M. Rafiqul, Limonene-Rich Liquids from Pyrolysis of Heavy Automotive Tire Wastes, $J$. Environ. Eng., 2007, 2, 681-695, DOI: 10.1299/jee.2.681.

52 M. Arabiourrutia, G. Lopez, G. Elordi, M. Olazar, R. Aguado, J. Bilbao. Product distribution obtained in the pyrolysis of tyres in a conical spouted bed reactor. 200762:5271-5275. DOI: 10.1016/j.ces.2006.12.026.

53 R. G. dos Santos, C. L. Rocha, F. L. S. Felipe, F. T. Cezario, P. J. Correia and S. Rezaei-Gomari, Tire waste management: an overview from chemical compounding to the pyrolysisderived fuels, J. Mater. Cycles Waste Manage., 2020, 22(3), 628-641, DOI: 10.1007/s10163-020-00986-8.

54 M. Labaki and M. Jeguirim, Thermochemical conversion of waste tyres-a review, Environ. Sci. Pollut. Res., 2017, 24(11), 9962-9992, DOI: 10.1007/s11356-016-7780-0.

55 J. D. Martínez, N. Cardona-Uribe, R. Murillo, T. García and J. M. López, Carbon black recovery from waste tire pyrolysis by demineralization: Production and application in rubber compounding, Waste Manage., 2019, 85, 574-584, DOI: 10.1016/j.wasman.2019.01.016.

56 S. Ucar, S. Karagoz, A. R. Ozkan and J. Yanik, Evaluation of two different scrap tires as hydrocarbon source by pyrolysis, Fuel, 2005, 84(14-15), 1884-1892, DOI: 10.1016/ j.fuel.2005.04.002.

57 P. T. Williams and A. J. Brindle, Fluidised bed pyrolysis and catalytic pyrolysis of scrap tyres, Environ. Technol., 2003, 24(7), 921-929, DOI: 10.1080/09593330309385629.

58 J. F. González, J. M. Encinar, J. L. Canito and J. J. Rodríguez, Pyrolysis of automobile tyre waste. Influence of operating variables and kinetics study, J. Anal. Appl. Pyrolysis, 2001, 58(59), 667-683, DOI: 10.1016/S0165-2370(00)00201-1.

59 Z. Feng and L. Zhu, Sorption of phenanthrene to biochar modified by base, Front. Environ. Sci. Eng., 2018, 12(2), 111, DOI: 10.1007/s11783-017-0978-7.

60 J. Maroušek, L. Kolář, M. Vochozka, V. Stehel and A. Maroušková, Biochar reduces nitrate level in red beet, Environ. Sci. Pollut. Res., 2018, 25(18), 18200-18203, DOI: 10.1007/s11356-018-2329-z.

61 M. Arabiourrutia, G. Lopez, M. Artetxe, J. Alvarez, J. Bilbao and M. Olazar, Waste tyre valorization by catalytic pyrolysis - A review, Renewable Sustainable Energy Rev., 2020, 129, 109932, DOI: 10.1016/j.rser.2020.109932.

62 R. Miandad, M. A. Barakat, M. Rehan, A. S. Aburiazaiza, J. Gardy and A. S. Nizami, Effect of advanced catalysts on tire waste pyrolysis oil, Process Saf. Environ. Prot., 2018, 116, 542-552, DOI: 10.1016/j.psep.2018.03.024.

63 P. T. Williams, Pyrolysis of waste tyres: A review, Waste Manage., 2013, 33(8), 1714-1728, DOI: 10.1016/ j.wasman.2013.05.003.
64 R. G. dos Santos, C. L. Rocha, F. L. S. Felipe, F. T. Cezario, P. J. Correia and S. Rezaei-Gomari, Tire waste management: an overview from chemical compounding to the pyrolysisderived fuels, J. Mater. Cycles Waste Manage., 2020, 22(3), 628-641, DOI: 10.1007/s10163-020-00986-8.

65 A. Demirbas, Higher heating values of lignin types from wood and non-wood lignocellulosic biomasses, Energy Sources, Part A, 2017, 39(6), 592-598, DOI: 10.1080/ 15567036.2016.1248798.

66 S. Elkhalifa, T. Al-Ansari, H. R. Mackey and G. McKay, Food waste to biochars through pyrolysis: A review, Resour., Conserv. Recycl., 2019, 144, 310-320, DOI: 10.1016/ j.resconrec.2019.01.024.

67 I. Barbarias, G. Lopez, M. Artetxe, A. Arregi, J. Bilbao and M. Olazar, Valorisation of different waste plastics by pyrolysis and in-line catalytic steam reforming for hydrogen production, Energy Convers. Manage., 2018, 156, 575-584, DOI: 10.1016/j.enconman.2017.11.048.

68 J. A. Conesa, I. Martín-Gullón, R. Font and J. Jauhiainen, Complete study of the pyrolysis and gasification of scrap tires in a pilot plant reactor, Environ. Sci. Technol., 2004, 38(11), 3189-3194, DOI: 10.1021/es034608u.

69 Series IOPC, Science M. Possibilities of carbon black recovery from waste tyre pyrolysis to be used as additive in rubber goods - a review-Possibilities of carbon black recovery from waste tyre pyrolysis to be used as additive in rubber goods - a review-, published online 2018. DOI: 10.1088/1757-899X/437/1/ 012012.

70 X. Zhang, H. Li, Q. Cao, L. Jin and F. Wang, Upgrading pyrolytic residue from waste tires to commercial carbon black, 2018, vol. 79, DOI: 10.1177/0734242X18764292.

71 C. Ilkiliç and H. Aydin, Fuel production from waste vehicle tires by catalytic pyrolysis and its application in a diesel engine, Fuel Process. Technol., 2011, 92(5), 1129-1135, DOI: 10.1016/j.fuproc.2011.01.009.

72 M. Mia, A. Islam, R. I. Rubel and M. R. Islam, Fractional Distillation \& Characterization of Tire Derived Pyrolysis Oil, Int. J. Eng. Technol., 2017, 3(1), 1-10.

73 A. Rowhani and T. J. Rainey, Scrap Tyre Management Pathways and Their Use as a Fuel - A Review, Energies, 2016, 9, 1-26, DOI: 10.3390/en9110888.

74 E. R. Umeki, C. F. De Oliveira, R. B. Torres and R. Gonçalves, Physico-chemistry properties of fuel blends composed of diesel and tire pyrolysis oil, Fuel, 2016, 185, 236-242, DOI: 10.1016/j.fuel.2016.07.092.

75 M. Karagöz, Ü. Ağbulut and S. Sarıdemir, Waste to energy: Production of waste tire pyrolysis oil and comprehensive analysis of its usability in diesel engines, Fuel, 2020, 275, 117844, DOI: 10.1016/j.fuel.2020.117844.

$76 \mathrm{~J}$. Rezaiyan and N. P. Cheremisinoff, Gasification Technologies: A Primer for Engineers and Scientists, CRC Press, 2005.

77 V. Belgiorno, G. De Feo, C. Della Rocca and R. M. A. Napoli, Energy from gasification of solid wastes, Waste Manage., 2003, 23(1), 1-15, DOI: 10.1016/S0956-053X(02)00149-6. 
78 I. Janajreh and S. S. RazaGasification of Waste Tires, Department of Mechanical and Materials Engineering, Masdar Institute of Science and Technology, 2002.

79 F. Fabry, C. Rehmet, V. Rohani and L. Fulcheri, Waste gasification by thermal plasma: A review, Waste Biomass Valorization, 2013, 4(3), 421-439, DOI: 10.1007/s12649013-9201-7.

80 C. Sathiskumar and S. Karthikeyan, Recycling of waste tires and its energy storage application of by-products -a review, Sustainable Mater. Technol., 2019, 22, e00125, DOI: 10.1016/ j.susmat.2019.e00125.

81 F. Campuzano, A. G. Abdul Jameel, W. Zhang, et al., Fuel and Chemical Properties of Waste Tire Pyrolysis Oil Derived from a Continuous Twin-Auger Reactor, Energy Fuels, 2020, 34(10), 12688-12702, DOI: 10.1021/ acs.energyfuels.0c02271.

82 R. Kumar Singh, B. Ruj, A. Jana, et al., Pyrolysis of three different categories of automotive tyre wastes: Product yield analysis and characterization, J. Anal. Appl. Pyrolysis, 2018, 135, 379-389, DOI: 10.1016/J.JAAP.2018.08.011.

83 N. Ahmad, F. Abnisa and W. M. A. Wan Daud, Liquefaction of natural rubber to liquid fuels via hydrous pyrolysis, Fuel, 2018, 218, 227-235, DOI: 10.1016/j.fuel.2017.12.117.

84 F. Xu, B. Wang, D. Yang, et al., TG-FTIR and Py-GC/MS study on pyrolysis mechanism and products distribution of waste bicycle tire, Energy Convers. Manage., 2018, 175, 288-297, DOI: 10.1016/j.enconman.2018.09.013.

85 L. Carmo-Calado, M. J. Hermoso-Orzáez, R. Mota-Panizio, B. Guilherme-Garcia and P. Brito, Co-combustion of waste tires and plastic-rubber wastes with biomass technical and environmental analysis, Sustain, 2020, 12(3), DOI: 10.3390/su12031036.

86 B. O. Oboirien and B. C. North, A review of waste tyre gasification, J. Environ. Chem. Eng., 2017, 5(5), 5169-5178, DOI: $10.1016 /$ j.jece.2017.09.057.

87 A. A. Ahmad, N. A. Zawawi, F. H. Kasim, A. Inayat and A. Khasri, Assessing the gasification performance of biomass: A review on biomass gasification process conditions, optimization and economic evaluation, Renewable Sustainable Energy Rev., 2016, 53, 1333-1347, DOI: 10.1016/j.rser.2015.09.030.

88 U. Lee, J. N. Chung and H. A. Ingley, High-temperature steam gasification of municipal solid waste, rubber, plastic and wood, Energy Fuels, 2014, 28, 4573-4587, DOI: 10.1021/ef500713j.

89 A. Abraham, M. Addy and A. F. Ahmad Shuhaili, et al., contributors, in Biofuels: Alternative Feedstocks and Conversion Processes for the Production of Liquid and Gaseous Biofuels, Academic Press, 2019, pp. 11-16. DOI: 10.1016/b978-0-12-816856-1.09992-9.

90 K. D. Panopoulos, L. E. Fryda and E. Kakaras, Atmospheric fluidised bed gasification of promising biomass fuels in Southern European regions, Therm. Sci., 2007, 11(1), 5-15, DOI: 10.2298/TSCI0701005P.

91 M. Campoy, A. Gómez-Barea, F. B. Vidal and P. Ollero, Airsteam gasification of biomass in a fluidised bed: Process optimisation by enriched air, Fuel Process. Technol., 2009, 90(5), 677-685, DOI: 10.1016/j.fuproc.2008.12.007.

92 P. Basu, Biomass Gasification, Pyrolysis and Torrefaction: Practical Design and Theory, Secind, Elsevier, 2013, DOI: 10.1016/C2011-0-07564-6.

93 F. Corona, D. Hidalgo, D. Díez-Rodríguez and A. Urueña, Conversion as the Key Step for the Production of ValueAdded Products from Waste, Biofuels, 2016, 1-26.

94 D. J. Roddy and C. Manson-Whitton, Biomass Gasification and Pyrolysis, vol. 5, Elsevier Ltd, 2012, DOI: 10.1016/ B978-0-08-087872-0.00514-X.

95 P. Quaak, H. Knoef and H. Sfassen, Energy from Biomass. A Review of Combustion and Gasification Technologies, 1999.

96 Z. A. B. Z. Alauddin, P. Lahijani, M. Mohammadi and A. R. Mohamed, Gasification of lignocellulosic biomass in fluidized beds for renewable energy development: A review, Renewable Sustainable Energy Rev., 2010, 14, 28522862, DOI: 10.1016/j.rser.2010.07.026.

97 K. Pattabhi Raman, W. P. Walawender and L. T. Fan, Gasification of waste tires in a fluid bed reactor, Conserv. Recycl., 1981, 4(2), 79-88, DOI: 10.1016/0361-3658(81) 90036-9.

98 V. Kirsanovs, A. Žandeckis, D. Blumberga and I. Veidenbergs, The influence of process temperature, equivalence ratio and fuel moisture content on gasification process: A review, in 27th International Conference on Efficiency, Cost, Optimization, Simulation and Environmental Impact of Energy Systems, ECOS 2014, Researc Gate, 2014.

99 J. A. Ruiz, M. C. Juárez, M. P. Morales, P. Muñoz and M. A. Mendívil, Biomass gasification for electricity generation: Review of current technology barriers, Renewable Sustainable Energy Rev., 2013, 18, 174-183, DOI: 10.1016/j.rser.2012.10.021.

100 N. D. Couto, V. B. Silva, E. Monteiro and A. Rouboa, Assessment of municipal solid wastes gasification in a semi-industrial gasifier using syngas quality indices, Energy, 2015, 93, 864-873, DOI: 10.1016/ j.energy.2015.09.064.

101 P. M. Lv, Z. H. Xiong, J. Chang, C. Z. Wu, Y. Chen and J. X. Zhu, An experimental study on biomass air-steam gasification in a fluidized bed, Bioresour. Technol., 2004, 95(1), 95-101, DOI: 10.1016/j.biortech.2004.02.003.

102 J. F. González, J. M. Encinar, C. M. González-García, et al., Preparation of activated carbons from used tyres by gasification with steam and carbon dioxide, Appl. Surf. Sci., 2006, 252(17), 5999-6004, DOI: 10.1016/ j.apsusc.2005.11.029.

103 H. Karatas, H. Olgun and F. Akgun, Experimental results of gasification of waste tire with air\&CO 2, air\&steam and steam in a bubbling fluidized bed gasifier, Fuel Process. Technol., 2012, 102, 166-174, DOI: 10.1016/ j.fuproc.2012.04.013.

104 H. Karatas, H. Olgun, B. Engin and F. Akgun, Experimental results of gasification of waste tire with air in a bubbling fluidized bed gasifier, Fuel, 2013, 105, 566-571, DOI: 10.1016/j.fuel.2012.08.038. 
105 J. S. Lee and S. D. Kim, Gasification kinetics of waste tirechar with CO2 in a thermobalance reactor, Energy, 1996, 21(5), 343-3352, DOI: 10.1016/0360-5442(95)00119-0.

106 A. Hasan and I. Dincer, Comparative assessment of various gasification fuels with waste tires for hydrogen production, Int. J. Hydrogen Energy, 2019, 44(34), 18818-18826, DOI: 10.1016/j.ijhydene.2018.11.150.

107 M. Rüegsegger and M. Kast, Lessons Learned about Thermal Biomass Gasification Report Elaborated 2016-2018 under IEA Bioenergy, Task 33 Thermal Gasification of Biomass and Waste, 2015, https://www.mendeley.com/catal ogue/201e0d29-0b8f-325c-824d-c6f4795609cf/?utm_source =desktop\&utm_medium=1.19.4\&utm_campaign =open_catalog\&userDocumentId=\%7B6eaf3dbf-ec4442c0-9bf5-2950521fa320\%7D.

108 I. Suarez-Ruiz, M. A. Diez and F. Rubiera, New Trends in Coal Conversion: Combustion, Gasification, Emissions, and Coking, Elsevier Science, 2018.

109 G. Bade, Coal gasification: American coal power's last, best chance?, Utility Dive, published December 14, 2014, https:// www.utilitydive.com/news/coal-gasification-american-coalpowers-last-best-chance/344911/.

110 F. Jin, H. Sun, C. Wu, et al., Effect of calcium addition on $\mathrm{Mg}$-AlOx supported $\mathrm{Ni}$ catalysts for hydrogen production from pyrolysis-gasification of biomass, Catal. Today, 2018, 309, 2-10, DOI: 10.1016/j.cattod.2018.01.004.

111 I. F. Elbaba and P. T. Williams, Deactivation of Nickel Catalysts by Sulfur and Carbon for the Pyrolysis-Catalytic Gasification/Reforming of Waste Tires for Hydrogen Production, Energy Fuels, 2014, 28(3), 2104-2113, DOI: 10.1021/ef4023477.

$112 \mathrm{C}$. Wu and P. T. Williams, Nickel-based catalysts for tar reduction in biomass gasification, Biofuels, 2011, 2(4), 451-464, DOI: 10.4155/bfs.11.113.

113 I. F. Elbaba and P. T. Williams, Two stage pyrolysis-catalytic gasification of waste tyres: Influence of process parameters, Appl. Catal., B, 2012, 125, 136-143, DOI: 10.1016/ j.apcatb.2012.05.020.

114 C. Wu and P. T. Williams, Hydrogen production from the pyrolysis-gasification of polypropylene: Influence of steam flow rate, carrier gas flow rate and gasification temperature, Energy Fuels, 2009, 23(10), 5055-5061, DOI: 10.1021/ef900278w.

115 A. S. Al-Rahbi and P. T. Williams, Hydrogen-rich syngas production and tar removal from biomass gasification using sacrificial tyre pyrolysis char, Appl. Energy, 2017, 190, 501-509, DOI: 10.1016/j.apenergy.2016.12.099.

116 I. F. Elbaba and P. T. Williams, High yield hydrogen from the pyrolysis-catalytic gasification of waste tyres with a nickel/dolomite catalyst, Fuel, 2013, 106, DOI: 10.1016/ j.fuel.2012.12.067.

117 I. F. Elbaba, C. Wu and P. T. Williams, Catalytic pyrolysisgasification of waste tire and tire elastomers for hydrogen production, Energy Fuels, 2010, 24(7), 3928-3935, DOI: 10.1021/ef100317b.

118 C. Wu and P. T. Williams, Pyrolysis-gasification of postconsumer municipal solid plastic waste for hydrogen production, Int. J. Hydrogen Energy, 2010, 35(3), 949-957, DOI: 10.1016/j.ijhydene.2009.11.045.

119 M. Cortazar, J. Alvarez, G. Lopez, et al., Role of temperature on gasification performance and tar composition in a fountain enhanced conical spouted bed reactor, Energy Convers. Manage., 2018, 171, 1589-1597, DOI: 10.1016/ j.enconman.2018.06.071.

120 M. Cortazar, G. Lopez, J. Alvarez, M. Amutio, J. Bilbao and M. Olazar, Advantages of confining the fountain in a conical spouted bed reactor for biomass steam gasification, Energy, 2018, 153, 455-463, DOI: 10.1016/ j.energy.2018.04.067.

121 G. Lopez, M. Cortazar, J. Alvarez, M. Amutio, J. Bilbao and M. Olazar, Assessment of a conical spouted with an enhanced fountain bed for biomass gasification, Fuel, 2017, 203, 825-831, DOI: 10.1016/j.fuel.2017.05.014.

122 Sasol. sasol-produces-15-billion-barrels-synthetic-fuel-coalfifty-years, published 2005, accessed December 11, 2019, https://www.sasol.com/media-centre/media-releases/sasolproduces-15-billion-barrels-synthetic-fuel-coal-fifty-years.

123 A. Kerester, Gasification Can Help Meet the World's Growing Demand for Cleaner Energy and Products, Cornerstone, 2014, 2(3), 5-10.

124 africary, The Theunissen $50 \mathrm{MW}$ Project, accessed January 7, 2020, http://www.africary.com/theunissen-project/.

125 Gross, C. D. M. V. der R. Eskom UCG Strategic Intent, in FFF \& IEA-CCC Conference "Underground Coal Gasification - Going Forward, 2011, https:/www.google.com/search?sxsrf= ALeKk03UwwICamBAUGLn8pKIVd6URYT6LQ\%

3A1600181218223\&ei=4tNgX5mADY-igQb9sp-

IBA\&q $=$ Chris + Gross + and + Dr+Mark+Van+der+Riet $\%$

2C+Eskom+UCG+Strategic+Intent $\% 2 \mathrm{C}+$ presented + at $+\mathrm{FFF}+\%$ 26+IEA-CCC+Conference\%

2C+"Underground+Coal+Gasificat.

126 Global Syngas Technologies Council, Worldwide Syngas Database, accessed December 19, 2019, https:// www.globalsyngas.org/resources/world-gasificationdatabase/.

127 W. M. Lewandowski, K. Januszewicz and W. Kosakowski, Efficiency and proportions of waste tyre pyrolysis products depending on the reactor type-A review, $J$. Anal. Appl. Pyrolysis, 2019, 140, 25-53, DOI: 10.1016/ j.jaap.2019.03.018.

128 S. Q. Li, Q. Yao, Y. Chi, J. H. Yan and K. F. Cen, Pilot-scale pyrolysis of scrap tires in a continuous rotary kiln reactor, Ind. Eng. Chem. Res., 2004, 43(17), 5133-5145, DOI: 10.1021/ie030115m.

$129 \mathrm{~J}$. Akhtar and N. Saidina Amin, A review on operating parameters for optimum liquid oil yield in biomass pyrolysis, Renewable Sustainable Energy Rev., 2012, 16(7), 5101-5109, DOI: 10.1016/j.rser.2012.05.033.

130 J. A. Garcia-Nunez, M. R. Pelaez-Samaniego, M. E. GarciaPerez, et al., Historical Developments of Pyrolysis Reactors: A Review, Energy Fuels, 2017, 31(6), 5751-5775, DOI: $10.1021 /$ acs.energyfuels.7b00641. 
131 M. Höök and K. Aleklett, A review on coal-to-liquid fuels and its coal consumption, Int. J. Energy Res., 2010, 34(10), 848-864, DOI: 10.1002/er.1596.

132 S. P. Sohi, E. Krull, E. Lopez-Capel and R. Bol, A review of biochar and its use and function in soil, Adv. Agron., 2010, 105, 47-82, DOI: 10.1016/S0065-2113(10)05002-9.

133 M. N. Islam and M. R. Nahian, Improvement of Waste Tire Pyrolysis Oil and Performance Test with Diesel in CI Engine, J. Renewable Energy, 2016, 1-8.

134 S. Frigo, M. Seggiani, M. Puccini and S. Vitolo, Liquid fuel production from waste tyre pyrolysis and its utilisation in a Diesel engine, Fuel, 2014, 116, 399-408.

135 L. Leng, H Li, X. Yuan, W. Zhou and H. Huang, Bio-oil upgrading by emulsification microemulsification: A review, Energy, 2018, 161, 214-232, DOI: 10.1016/ j.energy.2018.07.117.

136 I. Hita, M. Arabiourrutia, M. Olazar, J. Bilbao, J. M. Arandes. Opportunities and barriers for producing high quality fuels from the pyrolysis of scrap tires. 201656:745-759. DOI: 10.1016/j.rser.2015.11.081.

137 P. T. Williams, S. Besler, D. Taylor and T. BRP, The pyrolysis of automotive tyre waste, J. Inst. Energy, 1995, 68(474), 1121.

138 M. Kyari, A. Cunliffe and P. T. Williams, Characterization of oils, gases, and char in relation to the pyrolysis of different brands of scrap automotive tires, Energy Fuels, 2005, 19(3), 1165-1173, DOI: 10.1021/ef049686x.

139 A. Alsaleh and M. L. Sattler, Waste Tire Pyrolysis: Influential Parameters and Product Properties, Curr. Sustainable/ Renewable Energy Rep., 2014, 1(14), 129-135, DOI: 10.1007/s40518-014-0019-0.

140 M. F. Laresgoiti, I. De Marco, A. Torres, B. Caballero, M. A. Cabrero and M. J. Chomón, Chromatographic analysis of the gases obtained in tyre pyrolysis, J. Anal. Appl. Pyrolysis, 2000, 55(1), 43-54, DOI: 10.1016/S01652370(99)00073-X.

141 M. Rofiqul Islam, H. Haniu and M. Rafiqul Alam Beg, Liquid fuels and chemicals from pyrolysis of motorcycle tire waste: Product yields, compositions and related properties, Fuel, 2008, 87(13-14), 3112-3122, DOI: 10.1016/j.fuel.2008.04.036.

142 Y. Kar, Catalytic pyrolysis of car tire waste using expanded perlite, Waste Manage., 2011, 31(8), 1772-1782, DOI: 10.1016/j.wasman.2011.04.005.

143 G. Lopez, M. Olazar, R. Aguado, et al., Vacuum pyrolysis of waste tires by continuously feeding into a conical spouted bed reactor, Ind. Eng. Chem. Res., 2010, 49(19), 8990-8997, DOI: $10.1021 / \mathrm{ie} 1000604$.

144 C. Roy, H. Darmstadt, B. Benallal and C. Amen-Chen, Characterization of naphtha and carbon black obtained by vacuum pyrolysis of polyisoprene rubber, Fuel Process. Technol., 1997, 50(1), 87-103, DOI: 10.1016/S03783820(96)01044-2.

145 A. Lucchesi and G. Maschio, Semi-active carbon and aromatics produced by pyrolysis of scrap tires, Conserv. Recycl, 1983, 6(3), 85-90, DOI: 10.1016/0361-3658(83) 90033-4.
146 X. Zhang, T. Wang, L. Ma and J. Chang, Vacuum pyrolysis of waste tires with basic additives, Waste Manage., 2008, 28(11), 2301-2310, DOI: 10.1016/j.wasman.2007.10.009.

147 P. Parthasarathy, H. S. Choi, H. C. Park, et al., Influence of process conditions on product yield of waste tyre pyrolysisA review, Korean J. Chem. Eng., 2016, 33(8), 2268-2286, DOI: 10.1007/s11814-016-0126-2.

148 J. D. Martínez, R. Murillo, T. García and A. Veses, Demonstration of the waste tire pyrolysis process on pilot scale in a continuous auger reactor, J. Hazard. Mater., 2013, 261, 637-645, DOI: 10.1016/j.jhazmat.2013.07.077.

149 A. G. Buekens, Some observations on the recycling of plastics and rubber, Conserv. Recycl., 1977, 1(3-4), 247271, DOI: 10.1016/0361-3658(77)90014-5.

150 C. Roy, B. Labrecque and B. de Caumia, Recycling of scrap tires to oil and carbon black by vacuum pyrolysis, Resour., Conserv. Recycl., 1990, 4(3), 203-213, DOI: 10.1016/09213449(90)90002-L.

151 J. I. Osayi, S. Iyuke, M. O. Daramola, P. Osifo, I. J. Van Der Walt and S. E. Ogbeide, Pyrolytic conversion of used tyres to liquid fuel: characterization and effect of operating conditions, J. Mater. Cycles Waste Manage., 2018, 20(2), 1273-1285, DOI: 10.1007/s10163-017-0690-5.

152 M. Olazar, G. Lopez, M. Arabiourrutia, G. Elordi, R. Aguado and J. Bilbao, Kinetic modelling of tyre pyrolysis in a conical spouted bed reactor, J. Anal. Appl. Pyrolysis, 2008, 81(1), 127-132, DOI: 10.1016/j.jaap.2007.09.011.

153 M. Olazar, R. Aguado, J. Bilbao and A. Barona, Pyrolysis of sawdust in a conical spouted-bed reactor with a HZSM-5 catalyst, AIChE J., 2000, 46(5), 1025-1033, DOI: 10.1002/ aic.690460514.

154 M. Olazar, J. M. Arandes, G. Zabala, A. T. Aguayo and J. Bilbao, Design and Operation of a Catalytic Polymerization Reactor in a Dilute Spouted Bed Regime, Ind. Eng. Chem. Res., 1997, 36(5), 1637-1643, DOI: 10.1021/ie960616q.

155 J. Bilbao, M. Olazar, J. M. Arandes and A. Romero, Optimization of the operation in a reactor with continuous catalyst circulation in the gaseous benzyl alcohol polymerization, Chem. Eng. Commun., 1989, 75(1), 121-134, DOI: 10.1080/00986448908940672.

156 G. Lopez, J. Alvarez, M. Amutio, A. Arregi, J. Bilbao and M. Olazar, Assessment of steam gasification kinetics of the char from lignocellulosic biomass in a conical spouted bed reactor, Energy, 2016, 107, 493-501, DOI: 10.1016/j.energy.2016.04.040.

157 G. Lopez, M. Artetxe, M. Amutio, J. Alvarez, J. Bilbao and M. Olazar, Recent advances in the gasification of waste plastics. A critical overview, Renewable Sustainable Energy Rev., 2018, 82, 576-596, DOI: 10.1016/j.rser.2017.09.032.

158 G. Lopez, J. Alvarez, M. Amutio, et al., Kinetic modeling and experimental validation of biomass fast pyrolysis in a conical spouted bed reactor, Chem. Eng. J., 2019, 373, 677-686, DOI: 10.1016/j.cej.2019.05.072.

159 M. Olazar, G. Lopez, H. Altzibar, M. Amutio and J. Bilbao, Drying of Biomass in a Conical Spouted Bed with 
Different Types of Internal Devices, Drying Technol., 2012, 30(2), 207-216, DOI: 10.1080/07373937.2011.633194.

160 M. Olazar, G. Lopez, H. Altzibar and J. Bilbao, Modelling batch drying of sand in a draft-tube conical spouted bed, Chem. Eng. Res. Des., 2011, 89(10), 2054-2062, DOI: 10.1016/j.cherd.2011.01.012.

161 G. Lopez, M. Artetxe, M. Amutio, J. Bilbao and M. Olazar, Thermochemical routes for the valorization of waste polyolefinic plastics to produce fuels and chemicals. A review, Renewable Sustainable Energy Rev., 2017, 73, 346368, DOI: 10.1016/j.rser.2017.01.142.

162 N. M. Mkhize, B. Danon, J. Alvarez, et al., Influence of reactor and condensation system design on tyre pyrolysis products yields, J. Anal. Appl. Pyrolysis, 2019, 143, DOI: 10.1016/j.jaap.2019.104683.

163 I. F. Elbaba, C. Wu and P. T. Williams, Hydrogen production from the pyrolysis-gasification of waste tyres with a nickel/cerium catalyst, Int. J. Hydrogen Energy, 2011, 36(11), 6628-6637, DOI: 10.1016/ j.ijhydene.2011.02.135.

164 P. T. Williams and J. Onwudili, Subcritical and supercritical water gasification of cellulose, starch, glucose, and biomass waste, Energy Fuels, 2006, 20(3), 1259-1265, DOI: 10.1021/ ef0503055.

165 Y. Zhang and P. T. Williams, Carbon nanotubes and hydrogen production from the pyrolysis catalysis or catalytic-steam reforming of waste tyres, J. Anal. Appl. Pyrolysis, 2016, 122, 490-501, DOI: 10.1016/ j.jaap.2016.10.015.

166 D. Yao, C. Wu, H. Yang, et al., Co-production of hydrogen and carbon nanotubes from catalytic pyrolysis of waste plastics on Ni-Fe bimetallic catalyst, Energy Convers. Manage., 2017, 148, 692-700, DOI: 10.1016/ j.enconman.2017.06.012.

167 P. T. Williams, Pyrolysis; an environmentally attractive recycling route for used tyres, in Proceedings of the International Conference on Sustainable Waste Management and Recycling: Used/Post-Consumer Tyres, 2004, pp. 67-76, https://www.mendeley.com/catalogue/58bfa262-b793-3632b02c-e4e9e0787689/?

utm_source=desktop\&utm_medium $=1.19 .4 \& u t m \_$ campaign $=$ open_catalog\&userDocumentId $=\%$ 7B084bf738-02fb-417d-b5b3-79a6eed8bced\%7D.

168 P. T. Williams, A. M. Cunliffe and A. J. Brindle, Enhanced pyrolysis processing of scrap tyres, J. Inst. Energy, 2001, 74(501), 100-112.

169 P. T. Williams and J. Barton, Demonstration scale flash pyrolysis of municipal solid waste, in Proceedings of Institution of Civil Engineers: Waste and Resource Management, 2011, pp. 205-210, DOI: 10.1680/ warm.2011.164.3.205.

170 P. T. Williams, Valorization of printed circuit boards from waste electrical and electronic equipment by pyrolysis, Waste Biomass Valorization, 2010, 1(1), 107-120, DOI: 10.1007/s12649-009-9003-0.

171 P. T. Williams, Yield and Composition of Gases and Oils/ Waxes from the Feedstock Recycling of Waste Plastic, in
Feedstock Recycling and Pyrolysis of Waste Plastics: Converting Waste Plastics into Diesel and Other Fuels, ed. J. Scheirs and W. Kaminsky, Wiley Online Library, 2006, pp. 285-313, DOI: 10.1002/0470021543.

172 P. T. Williams and A. J. Brindle, Catalytic pyrolysis of tyres: Influence of catalyst temperature, Fuel, 2002, 81, 24252434, DOI: 10.1016/S0016-2361(02)00196-5.

173 P. T. Williams and A. J. Brindle, Fluidised bed catalytic pyrolysis of scrap tyres: Influence of catalyst:Tyre ratio and catalyst temperature, Waste Manage. Res., 2002, 20(6), 546-555, DOI: 10.1177/0734242X0202000609.

174 A. Chaala and C. Roy, Recycling of meat and bone meal animal feed by vacuum pyrolysis, Environ. Sci. Technol., 2003, 37(19), 4517-4522, DOI: 10.1021/es026346m.

$175 \mathrm{H}$. Pakdel and C. Roy, Recovery of bitumen by vacuum pyrolysis of Alberta tar sands, Energy Fuels, 2003, 17(5), 1145-1152, DOI: 10.1021/ef0300242.

176 A. Chaala and C. Roy, Preliminary investigation of the vacuum pyrolysis of bituminous roofing waste materials, J. Environ. Eng. Sci., 2003, 2(2), 119-126, DOI: 10.1139/S03008.

177 M. Garca-Pèrez, A. Chaala, J. Yang and C. Roy, Co-pyrolysis of sugarcane bagasse with petroleum residue. Part I: Thermogravimetric analysis, Fuel, 2001, 80(9), 1245-1258, DOI: 10.1016/S0016-2361(00)00215-5.

178 R. Miranda, H. Pakdel, C. Roy and C. Vasile, Vacuum pyrolysis of commingled plastics containing PVC II. Product analysis, Polym. Degrad. Stab., 2001, 73(1), 47-67, DOI: 10.1016/S0141-3910(01)00066-0.

179 R. Miranda, H. Pakdel, C. Roy, H. Darmstadt and C. Vasile, Vacuum pyrolysis of PVC II: product analysis, Polym. Degrad. Stab., 1999, 66(1), 107-125, DOI: 10.1016/S01413910(99)00060-9.

180 R. Miranda, J. Yang, C. Roy and C. Vasile, Vacuum pyrolysis of PVC I. Kinetic study, Polym. Degrad. Stab., 1999, 64(1), 127-144, DOI: 10.1016/S0141-3910(98)00186-4.

181 A. Chaala, H. Darmstadt and C. Roy, Vacuum pyrolysis of electric cable wastes, J. Anal. Appl. Pyrolysis, 1997, 39(1), 79-96, DOI: 10.1016/S0165-2370(96)00964-3.

182 H. Darmstadt, C. Roy and S. Kaliaguine, ESCA characterization of commercial carbon blacks and of carbon blacks from vacuum pyrolysis of used tires, Carbon, 1994, 32(8), 1399-1406, DOI: 10.1016/00086223(94)90132-5.

183 C. Roy and H. Darmstadt, Carbon blacks recovered from rubber waste by vacuum pyrolysis - Comparison with commercial grades, Plast., Rubber Compos. Process. Appl., 1998, 27(7), 341-345.

184 Q. Yang, L. Fu, X. Liu and M. Cheng, Evaluating the efficiency of municipal solid waste management in China, Int. J. Environ. Res. Public Health, 2018, 15(11), DOI: 10.3390/ijerph15112448.

185 D. Zhang, G. Huang, Y. Xu and Q. Gong, Waste-to-energy in China: Key challenges and opportunities, Energies, 2015, 8(12), 14182-14196, DOI: 10.3390/en81212422.

186 Markets R. and Waste-to-Energy (WtE) Market Trends, 2020-2025 - Growing Demand for Thermal-Based WtE 
Conversion, accessed June 20, 2020, https:// www.globenewswire.com/news-release/2020/03/06/ 1996445/0/en/Waste-to-Energy-WtE-Market-Trends-20202025-Growing-Demand-for-Thermal-Based-WtEConversion.html.

187 M. Margallo Blanco, Life cycle model of waste to energy technologies in Spain and Portugal, Univ Cantab, published online, 2014, p. 217. DOI: 10.1007/s00761-002-0403-z.

188 A. M. Almasi and L. Milios, Municipal Waste Management in Spain EEA, 2013. https:/www.eea.europa.eu/publications/ managing-municipal-solid-waste/spain-municipal-wastemanagement/view.

189 A. Venäläinen, B. Tammelin, H. Tuomenvirta, et al., The influence of climate change on energy production and heating energy demand in Finland, Energy Environ., 2004, 15(1), 93-109, DOI: 10.1260/095830504322986529.

190 Tuchten $\mathrm{HI}|\mathrm{KE}|$ O. and Goodbrand RL| S., Report on Sustainability 2017, 2017, http://www.claybrick.org/cba2017-sustainability-report.

191 Tyred and tested, Cape Bus News, published online 2016, accessed September 17, 2020, https:/www.cbn.co.za/ news/manufacturing/tyred-and-tested/.

192 Comments F. and Report R., National policy development process for high temperature waste incineration and AFR co-processing in cement production-Final comments and response report FINAL COMM, 2008 (August 2007).

193 Network Reporter, When it comes to tyres, what goes around comes around, IOL, published June 18, 2019, accessed May 18, 2020, https://www.iol.co.za/mercury/network/when-itcomes-to-tyres-what-goes-around-comes-around-26047584.

194 IRR Waste 2 Energy - International Rubber Recycling, published 2020, accessed March 2, 2020, http:// irrwaste2energy.com/.

195 Waste to Energy Solutions | recor, published 2020, accessed March 2, 2020, https://www.recor.co.za/waste-to-energysolutions.

196 Global Asset Management Limited, Integrated Annual Report, 2018, accessed September 17, 2020, http:// www.sacorporatefund.co.za/wp-content/uploads/2016/03/ Integrated-Annual-Report-2015.pdf.

197 L. Zhang, C. Charles Xu and P. Champagne, Overview of recent advances in thermo-chemical conversion of biomass, Energy Convers. Manage., 2010, 51(5), 969-982, DOI: 10.1016/j.enconman.2009.11.038.

198 R. H. Williams and E. D. Larson, A comparison of direct and indirect liquefaction technologies for making fluid fuels from coal, Energy Sustainable Dev., 2003, 7(4), 103129, DOI: 10.1016/S0973-0826(08)60382-8.

199 N. Ahmad, F. Abnisa, W. M. Ashri and W. Daud, Liquefaction of natural rubber to liquid fuels via hydrous pyrolysis, 2018. DOI: 10.1016/j.fuel.2017.12.117.

200 J. G. Speight, Production of syngas, synfuel, bio-oils, and biogas from coal, biomass, and opportunity fuels, in Fuel Flexible Energy Generation: Solid, Liquid and Gaseous Fuels, Elsevier Inc, 2016, pp. 145-174. DOI: 10.1016/B978-178242-378-2.00006-7.
201 R. E. Lumpkin, Recent progress in the direct liquefaction of coal, Science, 1988, 239(4842), 873-877, DOI: 10.1126/ science.239.4842.873.

202 B. G. Miller, Technologies for Coal Utilization, in Coal Energy Systems, Elsevier, 2005, pp. 195-281. DOI: 10.1016/ b978-012497451-7/50005-x.

203 M. Jahirul, M. Rasul, A. Chowdhury and N. Ashwath, Biofuels Production through Biomass Pyrolysis - A Technological Review, Energies, 2012, 5(12), 4952-5001, DOI: $10.3390 /$ en5124952.

204 M. Ringer, V. Putsche and J. Scahill, Large-Scale Pyrolysis Oil Production: A Technology Assessment and Economic Analysis, 2006, DOI: 10.2172/894989.

205 J. Autio, Fast pyrolysis demonstration - Increasing efficiency with integration to CHP, IEA Bioenergy Conference, 2016.

206 The research progress of biomass pyrolysis processes. Food and Agriculture Organization, accessed January 15, 2020, http://www.fao.org/3/t4470e/t4470e0a.htm.

207 Creating Bio-Oil from Wood Chips a Reality at Battelle, accessed January 15, 2020, https:/www.battelle.org/ newsroom/press-releases/press-releases-detail/creatingbio-oil-from-wood-chips-a-reality-at-battelle.

208 Who we are - BTG Bioliquids BV, accessed January 15, 2020, https://www.btg-btl.com/en/organisation.

209 C. Pfitzer, N. Dahmen, N. Tröger, et al., Fast Pyrolysis of Wheat Straw in the Bioliq Pilot Plant, Energy Fuels, 2016, 30(10), 8047-8054, DOI: 10.1021/acs.energyfuels.6b01412.

210 USDA, Agricultural Outlook Forum 2017, 2017, pp. 1-17.

211 J. L. Nocca, J. P. Burzynski and D. Sudolsky, Taking bio-R\&D to commercialization through partnering, Hydrocarb Process, 2016, 2016(MARCH):1-4, accessed January 18, 2020, http:/anellotech.com/sites/default/files/ HydroCarbonProcessingMagazine_2016.03.01.pdf.

212 N. Dahmen, A. Funke and J. Sauer, in IEA Bioenergy Conference 2015, IEA BIOENERGY, 2015, pp. 308-317, http://fnr.de/fileadmin/allgemein/pdf/broschueren/

GFG_Band_52_IEA_Bioenergy_Conference_web.pdf.

213 C. Contescu, S. Adhikari, N. Gallego, N. Evans and B. Biss, Activated Carbons Derived from High-Temperature Pyrolysis of Lignocellulosic Biomass, Journal of Carbon Research, 2018, 4(3), 51, DOI: 10.3390/c4030051.

214 Proton Power, Inc., 2017, accessed January 16, 2020, http:// www.protonpower.com/.

215 Trident Fuels - Waste to energy, accessed March 2, 2020, http://www.tridentfuels.co.za/.

216 Supply Chain Network - OSHO SA Recycling (pvt) Ltd, accessed April 27, 2020,https:/www.scnet.co.za/ Company.aspx?SMMEID $=69076$.

217 I. Venter, Mathe Group expands tyre recycling facility, despite Redisa demise, Creamer Media's Eng News, 2018, 9th April, accessed May 18, 2020, https:// www.engineeringnews.co.za/article/mathe-group-expandstyre-recycling-facility-despite-redisa-demise-2018-04-09.

218 Mthethwa P., Select Committee on Trade and Industry, Economic Development, Small Business Development, Tourism, Employment and Labour Room M515, 10h0013 h00 Parliament of the Republic of South Africa Ms 
Philisiwe Mthethwa (Chief Executive Officer) Championing Partners. 2019.

219 H. J. Huang, X. Z. Yuan, H. N. Zhu, et al., Comparative studies of thermochemical liquefaction characteristics of microalgae, lignocellulosic biomass and sewage sludge, Energy, 2013, 56, 52-60, DOI: 10.1016/j.energy.2013.04.065.

220 D. C. Elliott, D. Beckman, A. V. Bridgwater, J. P. Diebold, S. B. Gevert and Y. Solantausta, Developments in Direct Thermochemical Liquefaction of Biomass: 1983-1990, Energy Fuels, 1991, 5(3), 399-410, DOI: 10.1021/ ef00027a008.

221 S. Brand, R. F. Susanti, S. K. Kim, H. shik Lee, J. Kim and B. I. Sang, Supercritical ethanol as an enhanced medium for lignocellulosic biomass liquefaction: Influence of physical process parameters, Energy, 2013, 59, 173-182, DOI: 10.1016/j.energy.2013.06.049.

222 Y. Yang, A. Gilbert and C. Xu, Production of bio-crude from forestry waste by hydro-liquefaction in sub-/super-critical methanol, AIChE J., 2009, 55(3), 807-819, DOI: 10.1002/ aic.11701.

223 U. Jena, K. C. Das and J. R. Kastner, Effect of operating conditions of thermochemical liquefaction on biocrude production from Spirulina platensis, Bioresour. Technol., 2011, 102(10), 6221-6229, DOI: 10.1016/ j.biortech.2011.02.057.

224 Y. H. Chan, S. Yusup, A. T. Quitain, et al., Effect of process parameters on hydrothermal liquefaction of oil palm biomass for bio-oil production and its life cycle assessment, Energy Convers. Manage., 2015, 104(1), 180188, DOI: 10.1016/j.enconman.2015.03.075.

225 P. T. Williams, S. Besler and D. T. Taylor, The pyrolysis of scrap automotive tyres. The influence of temperature and heating rate on product composition, Fuel, 1990, 69, 1474-1482.

226 F. Behrendt, Y. Neubauer, M. Oevermann, B. Wilmes and N. Zobel, Direct liquefaction of biomass, Chem. Eng. Technol., 2008, 31(667), 677, DOI: 10.1002/ceat.200800077.

227 C. Vanasse, E. Chornet and R. P. Overend, Liquefaction of lignocellulosics in model solvents: Creosote oil and ethylene glycol, Can. J. Chem. Eng., 1988, 66(1), 112-120, DOI: $10.1002 /$ cjce.5450660116.

228 J. Chumpoo and P. Prasassarakich, Bio-oil from hydroliquefaction of bagasse in supercritical ethanol, Energy Fuels, 2010, 24(3), 2071-2077, DOI: 10.1021/ef901241e.

229 Y. Chen, Y. Wu, P. Zhang, et al., Direct liquefaction of Dunaliella tertiolecta for bio-oil in sub/supercritical ethanol-water, Bioresour. Technol., 2012, 124, 190-198, DOI: 10.1016/j.biortech.2012.08.013.

230 L. Nazari, Z. Yuan, S. Souzanchi, M. B. Ray and C. Xu, Hydrothermal liquefaction of woody biomass in hotcompressed water: Catalyst screening and comprehensive characterization of bio-crude oils, Fuel, 2015, 162, 74-83, DOI: 10.1016/j.fuel.2015.08.055.

231 H. Huang, X. Yuan, G. Zeng, et al., Thermochemical liquefaction characteristics of microalgae in sub- and supercritical ethanol, Fuel Process. Technol., 2011, 92(1), 147-153, DOI: 10.1016/j.fuproc.2010.09.018.
232 Y. Goldman, N. Garti, Y. Sasson, B.-Z. Ginzburg and M. R. Bloch, Conversion of halophilic algae into extractable oils, Fuel, 1980, 59, 181-184.

233 P. Duan and P. E. Savage, Hydrothermal liquefaction of a microalga with heterogeneous catalysts, Ind. Eng. Chem. Res., 2011, 50(1), 52-61, DOI: 10.1021/ie100758s.

234 T. O. Matsui, A. Nishihara, C. Ueda, M. Ohtsuki, N. O. Ikenaga and T. Suzuki, Liquefaction of micro-algae with iron catalyst, Fuel, 1997, 76(11), 1043-1048, DOI: 10.1016/S0016-2361(97)00120-8.

235 N. Ikenaga, C. Ueda, T. Matsui, M. Ohtsuki and T. Suzuki, Co-liquefaction of micro algae with coal using coal liquefaction catalysts, Energy Fuels, 2001, 15(2), 350-355, DOI: $10.1021 /$ ef000129u.

236 U. Jena, K. C. Das and J. R. Kastner, Comparison of the effects of $\mathrm{Na}_{2} \mathrm{CO}_{3}, \mathrm{Ca}_{3}\left(\mathrm{PO}_{4}\right)_{2}$, and $\mathrm{NiO}$ catalysts on the thermochemical liquefaction of microalga Spirulina platensis, Appl. Energy, 2012, 98, 368-375, DOI: 10.1016/ j.apenergy.2012.03.056.

237 United States Environmental Protection Agency, Environmental assessment database for coal liquefaction Technology: Volume 1, Systems for 13 liquefaction processes, Interagency Energy/Environmental R\&D Program Report, United States Environmental Protection Agency, 1978, Google Search. published 1978, accessed March 19, 2020. https://www.google.com/search?q=Environmental +assessment+database+for+coal+liquefaction+ Technology $\%$ $3 \mathrm{~A}+$ Volume +1 . + Systems + for $+13+$ liquefaction + processes $\%$ $2 \mathrm{C}+$ Interagency+Energy $\% 2 \mathrm{FEnvironmental+R} \%$ 26D+Program+Report.+United +States+Environmental+Protection+Agency.

238 Grand View Research, Coal To Liquid Market Size, CTL Industry Analysis Report, 2019-2026, 2017, accessed January 18, 2020. https://www.grandviewresearch.com/ industry-analysis/coal-to-liquid-ctl-market.

239 Anon, Coal technologies under development- Applications and status, Energy, 1982, 7, 21-22.

240 Anon, Co-processing of high sulfur coal, heavy oil demonstrated, Oil Gas J., 1989, 87(52), 133.

241 Headwaters, Axens form direct coal liquefaction alliance, Green Car Congress, 2010, DOI: 10.1016/s1351-4180(10) 70061-1.

242 I. Mochida, U. Priyanto, S. Murti, et al., Review on coal liquefaction technology, J. Jpn. Inst. Energy, 2001, 80(4), 237-252.

243 I. Mochida, O. Okuma and S. H. Yoon, Chemicals from direct coal liquefaction, Chem. Rev., 2014, 114(3), 16371672, DOI: $10.1021 /$ cr4002885.

244 B. Demirel, S. Mohedas, M. Ibsen and H. Wright. Rentech's coal-to-liquid process: An overview, in 24th Annual International Pittsburgh Coal Conference 2007, PCC 2007. 2007. vol. 3, pp. 1308-1313.

245 B. Demirel, Rentech process - Scale-up and commercialization of a coal-to-liquids process, in AIChE Annual Meeting, Conference Proceedings, 2007. 
246 B. Demirel, Rentech process - Scale-up and commercialization of a coal-to-liquids process, in 7th Topical Conference on Natural Gas Utilization 2007, Held at the 2007 AIChE Spring National Meeting, 2014, pp. 149152, https://www.mendeley.com/catalogue/63718777-f13e3556-bd74-47142919c218/?

utm_source=desktop\&utm_medium $=1$.

19.4\&utm_campaign=open_catalog\&userDocumentId $=\%$ 7Bbab4645e-5bd6-4843-b10c-ee0ee268ab06\%7D.

247 C. Ayasse and R. Ayasse, New syngas reforming solutions for enhanced gas to diesel conversion, in Society of
Petroleum Engineers - Abu Dhabi International Petroleum Exhibition and Conference, ADIPEC 2015. Society of Petroleum Engineers, 2015. DOI: 10.2118/177660-ms.

248 C. Ayasse and R. Ayasse, Using small-scale gas to liquids technology for flare gas mitigation, in Society of Petroleum Engineers - Abu Dhabi International Petroleum Exhibition and Conference 2016. Society of Petroleum Engineers, 2016, vol 2016-January, DOI: 10.2118/183161-ms.

249 E. Jin, Y. Zhang, L. He, H. G. Harris, B. Teng and M. Fan, Indirect coal to liquid technologies, Appl. Catal., A, 2014, 476, 158-174, DOI: 10.1016/j.apcata.2014.02.035. 